François Degeorge, François Derrien, Kent L. Womack

Quid pro quo in IPOs : why book-building is dominating auctions

Quaderno N. 04-05

Decanato della Facoltà di Scienze economiche

Via G. Buffi, $13 \mathrm{CH}-6900$ Lugano 


\title{
Quid Pro Quo in IPOs: Why Book-building is
}

\section{Dominating Auctions}

\author{
François Degeorge* \\ François Derrien** \\ Kent L. Womack***
}

This draft: November 2004

(*) University of Lugano

(**) Rotman School of Management, University of Toronto

$(* * *)$ Tuck School of Business, Dartmouth College

We thank Larry Ausubel, Dan Bradley, Clay Corbus, Bruno Husson, Jay Ritter, Ann Sherman and participants at the $3^{\text {rd }}$ EVI Conference at the Tuck School for helpful comments. Part of this research has been carried out within the project on Corporate Finance of the National Centre of Competence in Research "Financial Valuation and Risk Management" (NCCR FINRISK). The NCCR FINRISK is a research program supported by the Swiss National Science Foundation. Degeorge and Derrien also acknowledge support from the RICAFE program (HPSE-CT-2002-00140). Jens Martin and Sébastien Michenaud provided able research assistance. 


\title{
Quid Pro Quo in IPOs: Why Book-building is
}

\author{
Dominating Auctions
}

\begin{abstract}
The book-building procedure for selling initial public offerings to investors has captured significant market share from auction alternatives in recent years, despite significantly lower costs in both direct fees and initial underpricing when using the auction mechanism. This paper shows that in the French market, where the frequency of book-building and auctions was about equal in the 1990s, the ostensible advantages to the issuer using book-building were advertising-related quid pro quo benefits. Specifically, we find that book-built issues were more likely to be followed and positively recommended by the lead underwriters and were also more likely to receive "booster shots" post issuance if the shares had fallen. Even non-underwriters' analysts appear to promote book-built issues more, but only when their underwriters stood to gain from acquiring shares in future issues from the recommended firm's lead underwriter. Bookbuilt issues also appeared to garner more press in general (but only after they had chosen book-building, not before). Yet, we do not observe valuation or return differentials to suggest that these types of promotion have any value to the issuing firm. We conclude that underwriters using the book-building procedure have convinced issuers of the questionable value of advertising and promotion of their shares.
\end{abstract}




\section{1) Introduction}

To observe the underwriting scandals that have come to light in the U.S. since the market crash of 2000, one might think that the book-building mechanism used to price initial public offerings would be under attack. The reality, however, both in the U.S. and globally, is surprisingly the opposite. In France, for example, where the market was roughly equally split in the 1990s between auctioned and book-built IPOs, auctions are now virtually extinct. In Japan, when book-building was made available to issuers, IPO auctions instantaneously disappeared (See Kutsuna and Smith (2004)). Sherman (2003) reports that in virtually all countries where book-building has been introduced recently, pre-existing auction mechanisms have disappeared or lost significant market shares. In the U.S., competitors to the book-building underwriters such as W.R. Hambrecht that have attempted to create Dutch auctions for selling shares have not, as yet, been successful in gaining meaningful market share.

Convincing theoretical arguments for using auctions in IPOs exist as well as strong empirical support that auctions are less costly, not just in direct fees, but also in minimizing initial underpricing, which is a significant cost to the issuing company. Biais, Bossaert and Rochet (2002) and Biais and Faugeron-Crouzet (2002) show that welldesigned auction mechanisms allow underwriters to extract investors' information and to incorporate this information into the IPO price at a limited cost, a virtue previously attributed to book-building by Benveniste and Spindt (1989), Benveniste and Wilhelm (1990), and Sherman (2000). Derrien and Womack (2003) provide empirical support for auction theory in IPOs. They find that auctioned IPOs indeed exhibit lower underpricing than book-building, especially during "hot" IPO markets. 
Therefore, the central question we ask is: why do we observe the ostensible failure of auctions despite strong financial characteristics in their favor? Our hypothesis is that corporate issuers and investment banks are in a quid pro quo relationship that extends beyond the obvious direct costs: issuers are willing to pay the higher direct and indirect costs of book-building in exchange for increased and more favorable research coverage when they choose book-building rather than an auction. In a survey of issuers that switched underwriters between their IPO and their SEO, Krigman, Shaw and Womack (2001) find that the most important reason for switching was to enhance analyst coverage. Cliff and Denis (2003) provide evidence consistent with the hypothesis that issuers use IPO underpricing to "purchase" analyst coverage.

In order to test the quid pro quo hypothesis, we examine the behavior of security analysts following IPOs by book-building vs. IPOs by auction. While this comparison is impossible in the U.S., where book-building is the only procedure available, France offers an interesting investigation field: there, the two mechanisms coexisted for some time.

We find convincing empirical evidence that in addition to placing the IPO shares with investors, underwriters employing book-building implicitly commit to providing more favorable coverage to the companies they take public in the aftermarket. Specifically, we find that analysts affiliated with the lead underwriter of the offering issue more (and more favorable) recommendations for recent book-built IPOs than for auctioned offerings. We also find that these analysts provide "booster shots", that is, positive recommendations following poor stock market performance, to recent book-built IPOs. We do not observe this behavior in auctioned offerings. 
An important feature of the book-building mechanism is the complete discretion of the underwriter over the allocation of shares to investors. This feature of bookbuilding recently made financial headlines in the context of several IPO scandals. Unlawful underwriters' practices include “spinning”, i.e. giving underpriced IPO shares to executives of prospective investment banking clients in the hope of winning future underwriting business from them, and "laddering", the practice of giving generous IPO allocations to clients in return for the promise that they would buy more shares of the IPO company on the aftermarket. ${ }^{1}$

The discretion underwriters enjoy in the allocation of book-built IPO shares gives them a substantial amount of power. We hypothesize that lead underwriters use this power to "lean on" even unaffiliated analysts to provide positive coverage. We find empirical confirmation of this hypothesis. Specifically, we find that unaffiliated analysts issue positive recommendations on IPOs taken public by an underwriter if this underwriter is about to take another company public soon (using book-building). We do not observe this behavior for auctioned IPO underwriters.

We also examine press coverage of IPO companies, and find that, even though book-built IPOs are not more covered by the press before they go public (and before they choose their IPO procedure), they receive more press coverage after the IPO. We interpret this result as evidence that book-building underwriters use their resources to influence the press to advertise their recent offerings.

We find no evidence that companies choosing book-building benefit from the additional promotion they enjoy. Book-built offerings do not exhibit better long-term

\footnotetext{
${ }^{1}$ In April 2003, ten investment banks agreed to pay $\$ 1.4$ billion in a global settlement regarding an analyst conflict of interest probe by the SEC, the NYS Attorney General, and the NASD. Other recent examples can be found on Jay Ritter's web site (http://bear.cba.ufl.edu/ritter/ipolink.htm).
} 
performance, are priced at lower multiples, and have lower stock price performance in the year following good recommendations.

The rest of the paper is organized as follows. In Section 2, we present our hypotheses. In Section 3, we briefly describe the institutional features of the French IPO market. In Section 4, we describe the data used in the study. Section 5 presents our empirical results, Section 6 discusses our findings, and Section 7 concludes.

\section{2) Hypotheses}

Globally, book-building has become the most popular procedure for taking companies public by far. In fact, in many countries it is essentially the only method used. An alternative mechanism for selling a portion of the company to public investors is to conduct an auction. While auctions come in many flavors, it is generally accepted that they have attractive properties, in terms of eliciting information from market participants, and maximizing proceeds for the issuer. Moreover, Derrien and Womack (2003) report empirical evidence on the French IPO market, where both auctions and book-building were used to take companies public. They find that auctioned IPOs "leave less money on the table" at the offering (have lower initial returns) than book-built IPOs, especially in "hot" IPO markets. If auctions enable IPO issuers to raise more cash at lower cost, why do issuers often prefer book-building?

Our central hypothesis is that the book-building procedure entails a tacit agreement between issuers and banks. According to this "quid pro quo", issuers are willing to pay the higher direct and indirect costs of book-building in exchange for increased, and more favorable, analyst coverage. Thus, we hypothesize that in addition 
to placing the IPO shares, book-building underwriters implicitly commit to provide favorable coverage to IPOs in the aftermarket.

Coverage comes in several forms, research reports and analyst recommendations being among the most prominent. Obtaining favorable coverage for their stock ranks among the top concerns of the managers of IPO firms. For example, Krigman, Shaw and Womack (2001) document that the desire to increase reputable analyst coverage is a main reason for issuers to switch underwriters when they return to the equity market for an equity offering. Dunbar (2000) finds that IPO underwriters increase their market share if they have analysts in the Institutional Investor's All-American Research Team. Rajan and Servaes (1997) find that the intensity of analyst coverage is positively correlated with the degree of initial return. Cliff and Denis (2003) confirm this result, and find that postIPO analyst coverage is negatively correlated with the probability of switching underwriters between the IPO and the SEO. They conclude that issuers "purchase" analyst coverage with underpricing. One reason for this interest in analyst coverage is offered by Aggarwal, Krigman and Womack (2002). They develop a model in which issuers use underpricing to generate analyst coverage and maximize the stock price at the end of the lock-up period, that is, when they can sell their retained shares.

Providing coverage, especially favorable coverage, for an IPO stock, is not without costs for an underwriter. In addition to the cost of devoting human resources, there is potentially a reputational cost to be borne, if investors perceive that analyst recommendations are slanted. Yet recent newspaper headlines have shown that investment bankers are sometimes willing to bear such costs. Michaely and Womack 
(1999) find evidence suggesting that analyst recommendations for IPO stocks are tainted by conflict of interest.

We hypothesize that analysts affiliated with the IPO underwriter are more actively involved in supporting book-built IPOs than auctioned IPOs in the year following the offering. Our hypothesis yields a number of testable predictions. Relative to auctioned IPOs, affiliated analysts in book-built IPOs should provide (1) more analyst reports, (2) more recommendations, (3) more favorable recommendations, and (4) more recommendations when the stock price does poorly (known as "booster shots" - see Michaely and Womack (1999)).

In addition to the lead underwriter's direct contribution to coverage through research reports and recommendations, we hypothesize that the underwriters of bookbuilt IPOs also use their resources to influence the coverage of the IPO stocks by unaffiliated analysts and other third parties, such as the press. Influencing the press may be achieved simply through a targeted public-relations effort. The channels of influence using unaffiliated analysts are more subtle. An important feature of the book-building mechanism is the complete discretion of the underwriter over the allocation of shares in case of excess demand. This discretion gives the underwriter a substantial amount of power vis-à-vis investors and other brokerage firms. We hypothesize that underwriters may use this power to induce these banks to provide positive coverage to their recent IPOs.

Consider two investment banks, A and B. Bank A has taken company X public, and is going to take company Y public next month. Bank B was not a co-manager for the IPO of X, nor does it expect to be one for the IPO of Y. Yet Bank B hopes to obtain 
generous share allocations of IPO Y next month. One way to curry favor with Bank A is to issue favorable recommendations on the company X. Thus, we expect the coverage of a book-built IPO by analysts unaffiliated with the underwriter to be especially favorable when that same underwriter is about to take another company public using the bookbuilding mechanism.

If indeed book-built IPOs enjoy more promotion than auctioned IPOs, does this translate into tangible benefits for issuers? Such benefits might include higher valuation multiples, higher aftermarket liquidity, stronger long-term performance, or a better ability to raise additional funds from the equity market in the future.

\section{3) Institutional features of the French IPO market}

The French IPO market offers an ideal testing ground for the hypotheses developed in the previous section. Historically, two IPO mechanisms were used there: Offre à Prix Minimal, an auction mechanism, and Offre à Prix Ferme, a fixed-price mechanism. In 1993, the book-building procedure was made available to issuers by the stock market authorities. For a few years, these three mechanisms co-existed. In this paper, we consider auctioned and book-built IPOs between 1993 and 1998, a period over which the two mechanisms were roughly used with equal frequency.

The book-building mechanism used in France is similar to its North-American counterpart. ${ }^{2}$ A few weeks before the offering, the issuer and the lead underwriter (or book-manager) agree on an initial price range. Then the "road-show" starts, during which the underwriter and the issuer advertise the offering to potential investors. The

\footnotetext{
${ }^{2}$ For a more detailed description of the two listing mechanisms and institutional details of the French IPO market, see Derrien and Womack (2003).
} 
underwriter collects indications of interest from investors. These indications of interest specify a quantity of shares, and may or may not specify a price limit. They can be cancelled or modified before the offering. Right before the offering, the lead underwriter closes the order book, sets the IPO price and allocates the shares with complete discretion often to its largest or favourite customers.

In auctioned IPOs, the price setting and share allocation process is done in the following way. A few weeks before the shares start trading, the issuer and the underwriter agree on a minimum price. Investors are then asked to submit orders. These orders must contain a quantity and a limit price above the minimum price. Unlike indications of interest submitted in book-built offerings, these orders cannot be withdrawn before the offering. The orders are collected by the Paris Bourse. A few days before the IPO date, the Paris Bourse sets a maximum price, above which orders are eliminated, ${ }^{3}$ and proposes several IPO prices to the issuer. There is no written rule as to how these IPO prices are chosen, but discussions with issuers and Paris Bourse employees suggest that they are set slightly below the market clearing price. The issuer and the underwriter choose the IPO price from the set of prices proposed by the Paris Bourse. All orders with prices above the IPO price and below the maximum price are served at the IPO price, and rationing is done on a pro rata basis.

Thus, whereas the role of the underwriter is crucial in book-built offerings, it is much more modest in auctioned IPOs. Moreover, as is the case in most U.S. IPOs, bookbuilt offerings are associated with a firm commitment of the underwriter. On the

\footnotetext{
${ }^{3}$ The goal of this maximum price is to prevent investors from free-riding on the mechanism by placing orders at very high prices in order to get IPO shares that are underpriced on average.
} 
contrary, auctions are associated with "best effort" contracts, i.e. the underwriter is not committed to buying the shares that are left unsold to the public.

In our time period, French initial public offerings took place on three exchanges. The Premier Marché is the exchange on which the largest companies are traded. Except for a few large firms, few IPOs take place on this exchange, and issuers generally choose to list on the Second Marché or on the Nouveau Marché. Due to different listing requirements, the Second Marché attracts well-established mature companies, whereas the Nouveau Marché is designed for growth companies. This exchange was created in 1996 following the Nasdaq's model.

The French sell-side security analyst market is similar to its U.S. counterpart. However, contrary to the U.S. IPO market, there is no "quiet period" in France for IPO stocks. Therefore, there is no clustering of initiation of analyst coverage a few weeks after the offering, as is the case in the United States. ${ }^{4}$ Analyst coverage can start as early as the IPO date, or even before the company's shares are traded.

\section{4) The data}

Our IPO sample consists of book-built and auctioned IPOs completed on the French stock exchange. Since our goal is to compare auction and book-building, we focus on a period in which these two mechanisms were both in use. Thus, we restrict our IPO sample to the period between January 1993 and August 1998 when there were 204 IPOs. One-hundred fourteen of them were done by book-building and 90 were done by auction. (Since September 1998 and until December 2003, 170 companies have been

\footnotetext{
${ }^{4}$ See Bradley, Jordan, and Ritter (2003) on the initiation of analyst coverage at the end of the quiet period for U.S. IPOs.
} 
listed on the Paris stock exchange, and only 12 have used the auction mechanism.) Given the difference in size between Premier Marché IPOs and those completed on the two other exchanges and the fact that there were only 17 IPOs on the Premier Marché during our time period, we limit our sample to those completed on only the Second Marché and Nouveau Marché. We also ignore companies transferred from the Marché Libre, a transitory exchange that is comparable to the OTC market in the U.S. Indeed, informational issues may be less important for these companies, which were previously publicly traded before their IPO, than for "regular" offerings. Thus, our sample contains 204 initial public offerings.

Our data about the characteristics of the IPO firms and the details of the offering comes directly from preliminary prospectuses. This information consists of the financial statements of the company in the years preceding the offering, the IPO mechanism used, the number of shares offered, the initial price range (for book-built offerings) and minimum price (for auctions), and the names of lead underwriters and co-managers. For 12 auctioned IPOs, we were not able to identify the lead underwriters. In subsequent tests, whenever we examine hypotheses related to the behaviour of analysts affiliated to the lead underwriter, we eliminate these 12 offerings from our sample.

IPO prices were obtained from Euronext, as were aftermarket prices in the year following the IPO. The data on trading volume and bid-ask spreads in the year following the offering come from Datastream.

For each IPO in our sample, we collected analyst recommendations from the I/B/E/S analyst-by-analyst, "detail" recommendation database. We track analyst recommendations issued in the one year period following the IPO. For each 
recommendation, the date of the recommendation is available, as is the type of the recommendation (classified by I/B/E/S as 1: strong buy, 2: buy, 3: hold, 4: underperform, and 5: sell), and the name of the broker who issued the recommendation. Overall, we identified 845 such recommendations for the 204 IPOs in our sample.

We also collected information on the total number of reports written by analysts in the year following the offering and on the number of newspaper articles written about the IPO companies from six months before the offering to one year after the IPO. The number of reports is obtained from the Investext research database of Thomson Research For each IPO company, we know the number of reports that have been written in the year following the offering, as well as the name of the brokerage house that issued them. The number of newspaper articles in which the names of the IPO companies appeared in headlines or lead paragraphs was collected using Factiva.

Moreover, we hand-collected information on seasoned equity issues by our IPO companies in the five-year period following their initial offering from Euronext. This information contains the date and amount of each SEO.

\section{5) Empirical results}

\section{A. Summary statistics}

Table 1 presents descriptive statistics of our IPO sample.

[Insert Table 1 about here.]

In Table 1, Panel A, we present the number of IPOs per year, exchange, and industry. First, we notice that the proportion of book-built IPOs has increased over the 
period. Whereas between 1993 and 1997, the number of offerings using the two mechanisms was quite balanced, there were twice as many book-buildings as auctions between January and August 1998 (52 vs. 26). As for exchanges, the use of the two mechanisms is well balanced on the Second Marché. On the contrary, all Nouveau Marché IPOs have used the book-building mechanism, even though choice is permitted by the exchange authorities. The important role of the underwriter as well as the firm commitment contract associated with book-building may be used as a certification mechanism by Nouveau Marché offerings, which are young, growth companies, and for which the listing requirements are not as strict as for Second Marché IPOs. ${ }^{5}$ Industries are quite balanced between the two mechanisms, with a few exceptions: information technology companies seem to prefer the book-building mechanism, which is probably due to the fact that a large fraction of these IPOs are listed on the Nouveau Marché.

Table 1, Panel B presents the list of lead underwriters who managed our sample of IPOs. Three of the lead underwriters are not matched in the $\mathrm{I} / \mathrm{B} / \mathrm{E} / \mathrm{S}$ recommendation database. These three intermediaries were lead underwriters of 9 offerings ( 6 auctions and 3 book-buildings). ${ }^{6}$ In other cases the underwriter is not included in $\mathrm{I} / \mathrm{B} / \mathrm{E} / \mathrm{S}$, but one of their subsidiaries or their mother company is. In such cases, we consider the bank and its subsidiary as a single entity. Panel B of the table also shows that large underwriters are as likely to do auctions as book-building. In fact, the lead underwriter with the largest

\footnotetext{
${ }^{5}$ The intrinsic differences between Nouveau Marché and Second Marché offerings might have biased our statistical tests. We verified that when we eliminate Nouveau Marché offerings from our sample, our results are virtually unchanged.

${ }^{6}$ In subsequent tests, whenever we examine hypotheses related to the behavior of analysts affiliated to the lead underwriter, we eliminate these 9 IPOs.
} 
number of IPOs completed in the period was Banques Populaires, which appeared to specialize in auctions (33 of the 37 IPOs underwritten by this bank were auctions). ${ }^{7}$

In Table 1, Panel C, we present summary statistics on the IPO sample. Book-built IPO companies are on average larger than auctions. Their size also exhibits more variance (with an interquartile range of FF 431 million, vs. FF 161 million for auctions). On the Second Marché, large issuers tended to choose book-building. On the Nouveau Marché, where issuers are typically small, all IPOs have used book-building. Book-built offerings are also younger on average. They also use more underwriters (lead and comanagers) on average, and pay larger IPO fees (7.05\% vs. 5.53\% for auctioned IPOs). Note that the information on IPO fees was available for only a very small fraction of auctioned offerings (11 out of 90 such IPOs). This may explain why our results differ from the level of underwriting fees for auctioned offerings suggested by practitioners, which is closer to $3 \%$ of gross proceeds. Book-built issuers tend to do more SEOs in the five-year period following their IPO ( 0.51 per firm on average, compared to 0.28 for auctions). They also have larger initial underpricing, consistent with the findings of Derrien and Womack (2003).

\section{B. The IPO procedure chosen and levels of analyst coverage}

Table 2 presents statistics on the number of analyst reports and analyst recommendations issued in the year following the IPO for both mechanisms. The number of analyst reports is obtained from the Investext research database of Thomson Research, whereas individual recommendations come from the $\mathrm{I} / \mathrm{B} / \mathrm{E} / \mathrm{S}$ analyst-by-

\footnotetext{
${ }^{7}$ Since Banques Populaires accounts for about one third of the auctions in our sample, a legitimate concern is that our subsequent results might be driven by this specific bank. We checked that our results are robust when we remove the IPOs underwritten by this bank from our sample.
} 
analyst database. Both sources give the name of the broker that issued the report or the recommendation, which allows us to determine the affiliation of the analyst. ${ }^{8}$ An analyst can be coded as lead-affiliated, non lead-affiliated, or unaffiliated. We consider that the analyst is lead-affiliated if he or she works for the lead underwriter of the offering, or one of its subsidiaries, or its mother company. An analyst is non lead-affiliated if he or she works for a co-manager of the IPO (excluding the lead underwriter), one of its subsidiaries, or its mother company. All the analysts that are not affiliated with the lead underwriter or co-underwriters are considered unaffiliated.

[Insert Table 2 about here.]

The first column of Table 2, Panel A presents the number of analysts that issued at least one recommendation in the year following the offering. Lead-affiliated analysts do so much more frequently for book-buildings than for auctions: only $26 \%$ of auctions received at least one recommendation from their lead underwriter, as opposed to $62 \%$ of book-built IPOs. Unaffiliated analysts also issue more recommendations for book-built offerings: $71 \%$ of book-built IPO firms received unaffiliated recommendations, as opposed to $53 \%$ of auctions, and $18 \%$ of book-buildings received recommendations from more than 4 unaffiliated analysts, versus only $9 \%$ for auctions.

The second column of Table 2, Panel A breaks down our sample by the number of analyst research reports covering the IPO. Most companies are not covered at all in the year following their IPO. But book-built offerings attract the attention of more analysts than auctions: almost none of our auction sample IPOs had reports written by lead-

\footnotetext{
${ }^{8}$ Throughout the paper, we focus on the name of the brokers who issued reports or recommendations, not on the name of individual analysts, and we use the terms "broker" and "analyst" interchangeably.
} 
affiliated analysts, while more than $20 \%$ of book-built IPOs did. The same pattern holds, to a lesser extent, for non lead-affiliated and unaffiliated analysts.

The third column of Table 2, Panel A classifies offerings according to the number of recommendations received in the first year of their public life. Again, book-built IPOs attract more recommendations from lead-affiliated and unaffiliated analysts than their auctioned counterparts.

Table 2, Panel B confirms these results in a multivariate analysis. We run Poisson regressions where the dependent variables are the number of analysts issuing recommendations in the year following the IPO (columns 1, 4 and 7), the number of analyst reports (columns 2, 5 and 8), and the number of recommendations received (columns 3,6 and 9). The book-building dummy is the explanatory variable of principal interest. To avoid any left-over variable bias, we include other explanatory variables that are likely to influence analyst coverage, and may be correlated with the IPO procedure used. Rajan and Servaes (1997), Cliff and Denis (2003), and Aggarwal, Krigman, and Womack (2003) find that initial underpricing is strongly associated with analyst coverage, so we include initial returns as an independent variable. An IPO with more underwriters may benefit from greater coverage, hence we include the number of underwriters (lead and co-managers) as well. We include the stock exchange, firm size, IPO year and industry as control variables. ${ }^{9}$

The regressions in Table 2, Panel B strongly suggest that book-built offerings have greater analyst coverage - especially coverage from lead-affiliated analysts. For example, book-built IPOs receive about twice as many recommendations (and 19 times as many reports) from lead-affiliated analysts as auctions ( $p$-value $<5 \%$ ).

\footnotetext{
${ }^{9}$ To conserve space we do not report the coefficients on the industry or the IPO year dummy variables.
} 
However, our results might be affected by the endogeneity of the IPO mechanism. To address this issue, we use a two-stage methodology which has been used previously in comparable situations (see for instance Ljungqvist and Wilhelm (2003)). The principle of the methodology is to estimate first the probability of choosing the book-building mechanism as a function of exogenous variables. In the second stage, the book-building dummy variable is replaced by its estimated value using the results of the first stage. Table 1 gives a list of good candidates for our exogenous variables. Book-built IPOs are larger, younger than auctions. More secondary shares are sold in book-built IPOs. Moreover, Table 1 suggests that book-building was used more frequently at the end of our sample period. Also, firms in some industries may be more prone to use this IPO mechanism. We use these variables in a Probit regression in which the book-building dummy is the dependent variable. ${ }^{10}$ The results in Table 2, Panel C, show that these variables are good predictors of the probability of the book-building mechanism being used (Pseudo- $R^{2}=52 \%$ ). Next, we replicate our previous tests, replacing the bookbuilding dummy variable by its predicted value using the results of the first stage. Most of our previous results are confirmed. The coefficients on the estimated book-building variable are close to those we obtained in our previous tests, and statistical significance is similar.

\section{Are lead-affiliated analysts more bullish in book-built IPOs?}

\footnotetext{
${ }^{10}$ We exclude observations from the Nouveau Marché, on which the IPO mechanism is not a choice variable (all IPOs on this exchange have chosen the book-building mechanism so far).
} 
Are analyst recommendations more positive for book-built IPOs than for auctions? Our quid pro quo hypothesis predicts that affiliated analyst recommendations should be more positive in book-built deals.

[Insert Table 3 about here.]

In Table 3, Panel A, we consider all analyst recommendations issued within one year of the initial public offering for our sample of companies. ${ }^{11}$ Lead-affiliated analysts are more positive for book-built than for auctioned offerings: $82 \%$ of their recommendations on book-buildings are "strong buys" or "buys", compared to $67 \%$ for auctions. The same picture appears for non lead-affiliated analysts, whose recommendations are "strong buys" or "buys" $84 \%$ of the time for book-buildings (vs. $68 \%$ for auctions). Unaffiliated analysts exhibit no difference in bullishness across the two types of offerings.

These results are confirmed by the multiple regressions of Table 3, Panel B. We report ordered probit regressions in which each individual analyst recommendation is used as an observation. In order to take into account the fact that recommendations for the same company can be correlated and that some companies receive more recommendations than others, we calculate $z$-statistics using Huber's (1967) methodology. ${ }^{12}$ Both lead-affiliated and non lead-affiliated recommendations are significantly more positive for book-built than for auctioned offerings (i.e. the bookbuilding dummy variable exhibits a significantly negative sign at the $1 \%$ and at the $10 \%$

\footnotetext{
${ }^{11}$ Analysts mostly issue "strong buy" and "buy" recommendations for our sample of IPOs (71\% of the recommendations are of one of these two types), consistent with previously documented findings for seasoned companies (Womack (1996)).

${ }^{12}$ In the rest of the paper, we use the same methodology whenever different firms have different numbers of observations.
} 
level for lead-affiliated and non lead-affiliated recommendations respectively). Holding other variables at their sample means, the likelihood of receiving a "strong buy" recommendation from a lead-affiliated analyst increases by $19 \%$ (from $25 \%$ to $44 \%$ ) for book-built offerings, and the likelihood of receiving a positive ("strong buy" or "buy") recommendation increases by $22 \%$ (from $57 \%$ to $79 \%$ ). ${ }^{13}$ This result is consistent with our quid pro quo hypothesis. Unaffiliated analysts, on the contrary, do not issue more favorable recommendations for either of the two types of offerings.

In Table 3, Panel C, we consider the potential endogeneity of the choice of IPO mechanism. We repeat the tests above, replacing the book-building dummy variable by its predicted value using the results of the first stage regression we obtained in Table 2, Panel C. The results are very similar to those we obtain in previous tests, which confirms that endogeneity is not a major issue.

\section{Booster shots}

In Table 4, we explore analyst recommendations conditional on past stock price performance of IPO firms. Under the quid pro quo hypothesis, we are more likely to observe positive recommendations after poor performance from affiliated analysts, a practice known as giving "booster shots". Table 4, Panel A presents the number of analyst recommendations and their average type depending on the past stock price performance of the IPO. For each recommendation, past performance is calculated as the average daily buy-and-hold return since the offering adjusted using size and book-tomarket portfolios of seasoned companies. Seasoned companies are split into 5 size portfolios and 5 book-to-market portfolios, and each IPO is assigned to one of the 25

${ }^{13}$ See Greene (2003), p. 736, on the interpretation of ordered probit coefficients. 
size/book-to-market portfolios depending on its size and book-to-market values as of the IPO date.

[Insert Table 4 about here.]

Consistent with the quid pro quo hypothesis, the results in the first two columns of Table 4, Panel A suggest that lead-affiliated analysts provide "booster shots" to bookbuilding IPO firms: the worse the past performance, the more favorable the recommendation (the average recommendation type is 1.64 for recommendations in the third of bad performance, 1.96 in the good-past performance third). Moreover, almost half the recommendations for book-built IPOs coming from lead-affiliated analysts follow bad performance (Panel A, first column). In other cells of the table, analyst recommendations are almost always less favorable after bad performance than after good performance. In particular, analysts affiliated with lead underwriters of auctions do not seem more keen on providing recommendations after bad performance, and when they do so, they provide unfavorable recommendations (the average recommendation type is 2.23 for recommendations in the bottom third of performance, vs. 1.93 in the top third).

We examine in greater detail the "booster shot" phenomenon in Panels B and C of Table 4. In Panel B, we run ordered probit regressions in which the dependent variable is the type of recommendation. In addition to the usual set of control variables and a leadaffiliated dummy variable equal to 1 when the analyst is lead-affiliated, we create two interaction variables: Lead-affiliated ${ }^{*}$ negative past performance is equal to one when the analyst is lead-affiliated and the adjusted past performance since the offering is negative, 0 otherwise. (1-Lead-affiliated)*negative past performance is equal to one when the analyst is not lead-affiliated and the adjusted past performance since the offering is 
negative, 0 otherwise. We run this regression for book-built and auctioned IPOs separately.

For book-built offerings, the coefficient on the Lead-affiliated*negative past performance variable is negative, whereas the coefficient on the (1-Leadaffiliated)*negative past performance variable is significantly positive at the $1 \%$ level. Thus, after bad performance, lead-affiliated analysts issue more favorable recommendations while other analysts issue less favorable recommendations. These two coefficients are significantly different at the $1 \%$ level. This result confirms that "booster shots" are prevalent and significant for lead-affiliated analysts in book-built IPOs. The picture is opposite for auctions: the signs are reversed - that is, following poor stock price performance, lead-affiliated analysts issue less favorable recommendations, while other analysts issue more favorable recommendations. Lead-affiliated analysts administer "booster shots" in book-built IPOs, not in auctions.

In another variant of the "booster shot" phenomenon, Table 4, Panel C, examines the total number of positive recommendations ("buy" or "strong buy") given to an IPO by its lead-affiliated analysts in each month of the first post-IPO year. Our objective is to track whether analysts decide to issue positive recommendations on the basis of recent stock price performance. We run Poisson regressions in which the dependent variable is the number of positive recommendations for each firm/month pair. In addition to the usual set of control variables, we include a variable named Performance change and the number of months since the IPO. Performance change is equal to 1 in a month when the stock's price performance had been positive since the IPO but turned negative in the prior 
month. ${ }^{14}$ (This is exactly the situation in which a booster shot by the underwriter would be expected.)

The results in Table 4, Panel C reinforce the impression conveyed by Panels A and B. For book-built offerings, a recent negative change in stock price performance is associated with an increase in the monthly number of positive recommendations issued by lead-affiliated analysts: book-built IPOs receive about twice as many positive recommendations from lead-affiliated analysts when their performance changed from positive to negative recently (the coefficient of the Performance change variable is significantly positive at the $5 \%$ level). Such is not the case for auctioned offerings. ${ }^{15}$ Overall, the results presented in Table 4 are consistent with the "booster shot" hypothesis that lead-affiliated analysts support book-built IPOs (but not auctioned IPOs) by issuing favorable recommendations after poor stock price performance.

\section{E. Do unaffiliated analysts try to curry favor with the underwriter?}

Our attention so far has focused mostly on affiliated analysts. Next, we consider unaffiliated analysts, and examine their incentives to provide support to IPO stocks. Our conjecture (suggested to us by conversations with practitioners) is that book-building underwriters, who choose the allocation of shares, may also influence the behavior of unaffiliated analysts. In order for the lead underwriter to allocate generous amounts of shares to their clients, unaffiliated analysts may be induced to offer coverage that favors this underwriter. One way of doing this is by issuing favorable recommendations on the

\footnotetext{
${ }^{14}$ Past performance is calculated as the Cumulative Abnormal Return since the IPO, using comparable size and book-to-market portfolios as benchmarks.

${ }^{15}$ For auctioned offerings, we also find that the number of positive recommendations issued by leadaffiliated analysts decreases with the number of months since the IPO. We do not observe this phenomenon for book-built IPOs, which indicates that support by lead-affiliated analysts, in addition to being stronger for book-buildings than for auctions, also lasts longer.
} 
recent IPOs made by the underwriter. We might expect unaffiliated analysts to be especially prone to this ingratiating behavior when it is most valuable for the underwriter, that is, when the IPO has been doing poorly. This hypothesis, which we label the "currying favor" hypothesis, is only relevant for book-built IPOs, since the allocation of auctioned IPO share is non-discriminatory.

In Table 5, we test this hypothesis by counting the number of positive ("buy" or "strong buy") recommendations issued by unaffiliated analysts in two distinct situations: - when the lead underwriter of the IPO is underwriting another IPO before the end of the next month, ${ }^{16}$

- when the lead underwriter of the IPO is not underwriting another IPO before the end of the next month.

[Insert Table 5 about here.]

Table 5, Panel A shows that book-built IPOs receive more positive recommendations from unaffiliated analysts in the months when their lead underwriter is about to underwrite another book-built offering ( 0.22 on average) than in the months when this is not the case ( 0.17 on average). This phenomenon is most pronounced for firms in the bottom third of past performance: poor-performance IPOs receive three times as many unaffiliated positive recommendations per month on average when their lead underwriter is doing another book-building in the next month as when he is not (the difference is statistically significant at the $5 \%$ level).

\footnotetext{
${ }^{16}$ We believe that one month is a natural window to consider. Indeed, allocation decisions for book-built IPO shares are presumably not made more than a month in advance.
} 
We also find that when unaffiliated analysts' incentives to curry favor with the lead underwriter are low - that is, when the lead underwriter is not about to do another IPO soon - unaffiliated analysts issue more positive recommendations when past IPO performance is stronger. This association breaks down when unaffiliated analysts' incentives to curry favor with the underwriter are high -- that is, when the lead underwriter is due to take another company public in the coming month.

Unlike book-built offerings, auctioned IPOs do not exhibit this result. The number of unaffiliated positive recommendations per month is quite similar independently of whether the underwriter is doing another IPO in the following month.

These results are confirmed in the Poisson regressions presented in Table 5, Panel B. In the first column of the table, we consider book-built IPO firms. The New IPO in the next month variable, equal to 1 when the lead underwriter of the offering is underwriting an IPO the next month, is positively associated with the monthly number of unaffiliated positive recommendations received by an IPO firm ( $p$-value: $6 \%$ ). The coefficient is larger and statistically significant at the $5 \%$ level when we consider firm/month pairs in the bottom third of past performance only (in the third column): book-built IPOs in the bottom third of past performance receive $53 \%$ more positive recommendations from unaffiliated analysts when their underwriter is about to underwrite another book-building in the next month. Again, no such pattern appears for auctioned IPOs (see columns 2 and 4 of Table 5, Panel B).

\section{F. IPO procedure and press coverage}

If book-building underwriters want to support the aftermarket price of the IPO stocks they underwrite, they may also influence other information sources by providing 
them with more (presumably favorable) information about the firm's prospects. In Table 6, we consider the coverage of book-built vs. auctioned offerings in the press. For each IPO in our sample, we count the number of newspaper articles in which the firm's name appeared in the headline or lead paragraph in the year following its offering.

[Insert Table 6 about here.]

In Panel A of the table, we classify IPO firms depending on the number of newspaper quotes received in the year following the offering. Book-built offerings appear to be significantly more covered by the press than auctioned IPOs: only a quarter of book-built IPO firms receive ten newspaper quotes or less in the year following their IPO, compared to more than $50 \%$ of auctions, and about a quarter are cited in more than 30 newspaper articles (vs. about 7\% for auctions). This is confirmed in the first column of Table 6, Panel B. In a multivariate analysis controlling for size, industry and other IPO characteristics, we find that the number of articles covering a book-built IPO is $38 \%$ higher than for auctioned IPOs ( $p$-value: $2 \%$ ).

Might book-built IPOs be intrinsically more visible or attractive to the press? We examine this possibility by considering press coverage before the offering. Typically, IPOs choose their underwriter and IPO procedure about three months before the offering. Before that date, any difference in press coverage is likely attributable to intrinsic visibility differences. From that date onward, the underwriter's incentives to advertise the IPO in the press are in place.

We split the six-month period before the IPO into two three-month periods, assumed to correspond to before and after the firm chooses its IPO procedure. Table 6 , Panel A, suggests that book-built offerings receive more press coverage only after they 
have chosen the book-building mechanism. Before they choose their IPO procedure, auctioned IPOs receive about the same amount of press coverage as book-built IPOs (70\% of book-built IPO firms are never cited in the press, as opposed to $62 \%$ of auctions).

After issuers choose their IPO procedure (in the three months preceding the offering), the picture becomes consistent with the post-IPO press coverage: only $26 \%$ of book-built IPOs receive five newspaper quotes or less (compared to $64 \%$ of auctions), and $39 \%$ receive more than ten (compared to $8 \%$ for auctions). This result is confirmed in Table 6, Panel B. In the three-month period preceding the offering, book-built IPOs receive 50\% more press coverage than auctions ( $p$-value: $0.1 \%$ ). Thus, the extra press coverage enjoyed by book-built IPO firms appears to be the result of their IPO procedure, rather than other intrinsic company characteristics.

\section{G. Do investors disentangle analysts' incentives?}

Next, we consider whether investors disentangle analysts' incentives by looking at stock price reactions to positive ("strong buy" or "buy") recommendations for all types of security analysts and the two types of IPO mechanisms. If investors are suspicious of analysts' incentives, they should discount positive recommendations by lead-affiliated analysts, especially when these recommendations are likely to be "booster shots" meant to prop up an IPO's faltering price.

[Insert Table 7 about here.]

Table 7, Panel A reports the stock price reaction to positive recommendations, measured by performance between recommendation date minus one day and 
recommendation date plus one day adjusted using size and book-to-market portfolios. This reaction is significantly positive in two situations: when non lead-affiliated analysts issue positive recommendations about book-built IPO firms, and when unaffiliated analysts issue positive recommendations about auctioned IPO firms. This is consistent with the "skeptical market" hypothesis of Bradley, Jordan and Ritter (2004), that is, with investors' rationality and our previous findings that these analysts seem to provide honest recommendations. More surprising is the positive mean reaction to positive recommendations from lead-affiliated analysts for book-built IPOs.

Next, we explore this point in greater detail. Our previous results indicate that lead-affiliated analysts issue (presumably biased) positive recommendations in order to support the stock price of their IPO firms only when their performance has been disappointing. In Table 7, Panel B, we examine reactions to lead-affiliated analyst positive recommendations for book-buildings, depending on the past performance of the IPO. Consistent with the "skeptical market" view, we find a large difference between reactions to recommendations following bad performance and those that follow good performance: $-0.65 \%$ vs. $5.79 \%$ on average, $-0.62 \%$ vs. $1.95 \%$ for the median, respectively. The average (median) price reactions for firms in the top and bottom thirds of past performance are statistically significantly different from each other at the $5 \%$ (the $10 \%)$ level. This suggests that investors understand the incentives of lead-affiliated analysts, and react favorably to their positive recommendations only when they follow good past performance. Auctioned offerings exhibit no such effect.

Panels C and D of Table 7 examine the one-year stock price performance following positive recommendations. One-year performance starting two days after the 
recommendation is calculated as a buy-and-hold return adjusted using size and book-tomarket portfolios. Median one-year performances following positive recommendations are statistically significantly negative for all types of analysts for book-built IPO companies (at the $5 \%$ level, the $10 \%$ level, and the $5 \%$ level for lead-affiliated, non leadaffiliated, and unaffiliated analysts, respectively).

In Table 7, Panel D, we present multiple regressions in which the dependent variable is one-year stock price performance following positive recommendations. We find that the coefficient of the book-building dummy variable is significantly negative at the 5\% level when we consider lead-affiliated recommendations: after a positive recommendation from a lead-affiliated analyst, book-built IPOs underperform auctions by $39 \%$ on average. If negative average stock price performance following positive recommendations is associated with analyst's bias at the time he or she issues the recommendation, this result is consistent with our previous findings on the behavior of lead-affiliated analysts.

\section{H. Do book-built IPOs benefit from the additional promotion they enjoy?}

We have found that book-built IPOs enjoy a significant amount of additional promotion relative to auctioned IPOs. Does this translate into tangible benefits for the issuers? Possible benefits include higher valuation multiples, higher aftermarket liquidity, stronger long-term performance, and a greater ability to raise funds from the equity market in the future. We now examine whether issuing companies choosing bookbuilding enjoy these benefits. We report our findings in Table 8 .

[Insert Table 8 about here.] 
In a nutshell, we find no evidence of such benefits for book-built offerings. First, we regress the book-to-market value of our IPO firms calculated ten days after the offering ${ }^{17}$ against a set of control variables and a book-building dummy variable. The coefficient on the book-building variable is equal to $9.2 \%$ and is significantly positive at the $5 \%$ level, indicating that, other things equal, book-built offerings have book-tomarket values about $10 \%$ above those of their auctioned counterparts at the IPO date. Thus, book-built offerings have relatively lower IPO valuations than auctions.

Next, we compare the one-year stock performance of the two types of offerings. One-year performance starting ten days after the IPO is calculated as a buy-and-hold return adjusted using size and book-to-market portfolios. Book-built IPOs slightly underperform auctions, but not significantly so.

The three measures of liquidity we use in the next regressions are the average trading volume, the average turnover, and the average bid-ask spread (normalized by the mid-price) in the year following the IPO. The regression in column 2 indicates that bookbuilding companies have higher trading volume than auctions, but in the two regressions presented in columns 3 and 4 of the table, they do not appear to have larger turnover or lower bid-ask spreads.

Finally, we consider seasoned equity offerings done in the five-year period following the IPO, both in terms of number of SEOs done during this period and total amount raised. In Panel $\mathrm{C}$ of Table 1, we observed that book-built offerings did more SEOs in the next five years than auctions on average. However, this result does not hold up in the multivariate analysis of Table 8 , columns 5 and 6 .

\footnotetext{
${ }^{17}$ We consider market capitalization using the price at the end of the $10^{\text {th }}$ trading day instead of the IPO price because a higher degree of underpricing (i.e. a lower IPO price) may be chosen by book-building issuers in order to elicit information production.
} 
In Table 8, Panel B, we replicate these tests using two-stage least squares. Our conclusions are unchanged: book-built IPOs are not priced at higher multiples, do not exhibit higher stock performance, liquidity or probability of returning to the market in the years following their IPOs.

\section{6) Discussion}

Our central argument is that issuers are willing to pay the higher costs of bookbuilding in exchange for increased and more favorable analyst coverage when they choose book-building rather than an auction. Why, then, does book-building dominate auctions - and why did book-building crowd out auctions in France after $1998 ?$ Loughran and Ritter (2004) argue that a shift occurred in the late 1990s, especially during the Internet bubble, whereby issuing firms placed increasing weight on analyst coverage. They call this the "analyst lust" hypothesis, and they argue that it can explain in part the surge in IPO underpricing during that period. We conjecture that a similar shift occurred outside the U.S., and that it contributed to the demise of IPO auctions in France. Faced with a choice between auctions (low cost, low coverage) and book-building (high cost, high coverage), firms increasing chose the latter as the perceived importance of analyst coverage grew. ${ }^{18}$

In addition to explaining the preference for book-building, our evidence also sheds light on the issue of the conflicts of interests faced by underwriter-linked analysts in IPOs. Michaely and Womack (1999) provide evidence consistent with a conflict of interest. On a sample of U.S. IPOs, they find that underwriter analyst recommendations

\footnotetext{
${ }^{18}$ One of the forces underlying Loughran and Ritter's "analyst lust" hypothesis is the increase in company valuations in the late 1990s. When companies' growth opportunities fetch higher prices, a small change in expected growth rates results in a larger change in selling price, leading companies to place greater weight on analyst coverage.
} 
are more bullish than recommendations from unaffiliated analysts. However their evidence is also consistent with Kahneman and Lovallo's (1993) "inside view." According to this view, affiliated analysts view the IPO their bank took public in a narrow frame. Like parents who view their children as special, they are unable to accept the statistical reality that many of their IPOs will turn out to be average or below average, and therefore, they are more likely to issue bullish recommendations than unaffiliated analysts, who are more willing to take a cold-hearted "outside view." If underwriter analyst bullishness were only due to the "inside view" explanation, we would expect no difference in coverage or bullishness between auctioned IPOs and book-built IPOs. Hence our evidence provides additional support for the conflict of interest explanation of underwriter analyst bullishness.

Some of our evidence may be loosely related to theories of information production in IPOs. For example, Chemmanur and Liu (2002) develop a model in which the goal of issuers is to maximize the long-term value of their stock. In this model, company insiders are informed and outsiders are uninformed but can acquire information at a cost. The gains from acquiring information are competed away in auctions, whereas a non-auction mechanism (such as book-building) allows underwriters to reward informed investors with underpriced shares. Therefore, book-building may generate more information production than auctions. A natural prediction of this model is that in equilibrium, firms of higher "quality" (i.e., of higher intrinsic value) choose bookbuilding over auctions, in order to maximize information production and consequently long-term value. The predictions of their model are in part similar to those of our "quid pro quo" story: both frameworks predict lower visibility for auctions, in the form of press 
coverage or analyst recommendations. Unlike our "quid pro quo" argument, the Chemmanur and Liu (2002) argument does not predict that coverage will be less slanted for auctioned IPOs, only that it will be less abundant.

\section{7) Conclusion}

Two facts appear indisputable. First, book-building as a selling procedure for initial public offerings has captured most of the market share in most important global equity financing markets in the last 5 years. Second, and not inconsequentially, is the fact that book-building is by far the most costly procedure available in terms of direct fees and indirect initial underpricing. Together, these points beg an important question of what benefits issuers must believe they are receiving for paying extra. The answer is not obvious at first blush.

Our evidence supports the claim that in France where book-building and auctions were equally popular for much of the 1990s, underwriters and issuers had a noncontractual quid pro quo arrangement where book-building underwriters promoted the issuing company through more positive research and press coverage. Not only were the lead underwriters involved, but unaffiliated analysts as well. We document that analysts at unaffiliated investment banks also were more likely to promote a book-built issue if they stood to gain shares in future deals from the book-building underwriter.

We find no evidence that the extra compensation paid to book-building underwriters pays future dividends. Book-built IPOs are no more likely to have longerterm higher returns relative to auctioned shares following positive recommendations. In other words, investors in the long run appear able to disentangle analysts' and their banks' incentives in book-built IPOs. Thus, even though book-building, with its higher 
direct costs, is more lucrative to investment banks, we find no evidence that this mechanism helps issuers. Maybe book-building is a better mechanism than auctions in some aspects not considered in this paper, but if so, its tangible advantages have yet to be articulated and empirically documented. 


\section{References}

Aggarwal, R.K., L. Krigman, and K. Womack, 2002, "Strategic IPO underpricing, information momentum, and lockup expiration selling", Journal of Financial Economics $66,105-137$.

Benveniste, L., and P. Spindt, 1989, "How investment bankers determine the offer price and allocation of new issues", Journal of Financial Economics 24, 343-361.

Benveniste, L., and W. Wilhelm, 1990, “A comparative analysis of IPO proceeds under alternative regulatory regimes", Journal of Financial Economics 28, 173-207.

Biais, B., P, Bossaert, and J.C. Rochet, 2002, “An optimal IPO mechanism”, Review of Economic Studies 69, 999-1017.

Biais, B., and A.M. Faugeron-Crouzet, 2002, "IPO auctions: English, Dutch,..., French, and Internet", Journal of Financial Intermediation 11, 9-36.

Bradley, D., B. Jordan, and J. Ritter, 2003, "The quiet period goes out with a bang", Journal of Finance 58, 1-36.

Bradley, D., B. Jordan, and J. Ritter, 2004, “Analyst behavior following IPOs: the 'Bubble period' evidence", working paper, University of Florida.

Chemmanur, T.J., and H. Liu, 2002, "How should a firm go public? A dynamic model of the choice between fixed-price offerings and auctions in IPOs and privatizations", working paper, Boston College.

Chen, H., and J. Ritter, 2000, “The seven percent solution”, Journal of Finance 55, 1105 1131.

Cliff, M.T., and D.J. Denis, 2003, "Do IPO firms purchase analyst coverage with underpricing?", forthcoming, Journal of Finance.

Derrien, F., and K. L. Womack, 2003, "Auctions vs. book-building and the control of underpricing in hot IPO markets", Review of Financial Studies 16, 31-61.

Dunbar, C.G., 2000, "Factors affecting investment bank initial public offering market share", Journal of Financial Economics 55, 3-41.

Greene, W.H., 2003, “Econometric Analysis”, Prentice Hall. 
Habib, M.A., and A. Ljungqvist, 2001, "Underpricing and entrepreneurial wealth losses in IPOs: theory and evidence", Review of Financial Studies 14, 433-458.

Huber, P.J., 1967, "The behavior of maximum likelihood estimates under non-standard conditions", Proceedings of the fifth Berkeley symposium on mathematical statistics and probability, University of California Press, 221-233.

Kahneman, D., and D. Lovallo, 1993, "Timid choices and bold forecasts: A cognitive perspective on risk taking," Management Science 39, 17-31.

Krigman, L., W. Shaw, and K.L. Womack, 2001, "Why do firms switch underwriters?", Journal of Financial Economics 60, 245-284.

Kutsuna, K., and R. Smith, 2004, "Why does book-building drive out auction methods of IPO issuance? Evidence from Japan”, Review of Financial Studies, forthcoming.

Ljungqvist, A., F. Marston, and W. Wilhelm, 2003, "Competing for securities underwriting mandates: banking relationships and analyst recommendations", working paper, New York University.

Loughran, and T., J. Ritter, 1994, "Why has IPO underpricing changed over time?", working paper, University of Florida.

Loughran, T., J. Ritter, and K. Rydqvist, 1994, "Initial Public Offerings: international insights", Pacific-Basin Journal of Finance 2, 165-199.

Michaely, R., and K.L. Womack, 1999, "Conflicts of interest and the credibility of underwriter analyst recommendations”, Review of Financial Studies 12, 653-686.

Sherman, A., 2000, "IPOs and long-term relationships: an advantage to book-building", Review of Financial Studies 13, 697-714.

Sherman, A., 2003, "Global trends in IPO methods: book-building vs. auctions", working paper, University of Notre-Dame.

Womack, K.L., 1996, “Do Brokerage Analysts' Recommendations Have Investment Value?”, Journal of Finance 51, 137-157. 
Table 1

Descriptive statistics

The sample consists of 204 offerings (114 book-buildings and 90 auctions) completed between January 1993 and August 1998 on the Second Marché and Nouveau Marché of the Paris stock exchange.

Panel A presents the number of IPOs per year, exchange and industry for the two mechanisms.

Panel B presents the lead underwriters' names, and for each of them, the number of auctions and book-buildings in which he was lead underwriter. Recs not recorded in $I / B / E / S$ in the column to the right of the table indicates that the recommendations made by the underwriter's brokerage house are not recorded in the I/B/E/S database.

Panel C presents summary statistics of the sample IPOs per listing mechanism. Market capitalization is the total number of shares post-issue times the IPO price, in millions of French Francs. Secondary shares is the number of pre-IPO shares sold in the offering divided by the total number of shares outstanding after the IPO. Age is the age of the company as at IPO date. Book-to-market is the ratio of book to market value of equity as at IPO date. Number of underwriters is the total number of deal managers involved in the IPO. Underwriting fees is the ratio of fees paid to the underwriters to gross proceeds. Number of SEOs is the number of equity offerings in the five years following the IPO. Initial return is the percent difference between the IPO price and the closing price at the end of the $10^{\text {th }}$ trading day. $I Q R$ is the interquartile range.

Panel A: Number of observations per IPO year, exchange and industry

\begin{tabular}{|c|c|c|c|c|}
\hline & Book-building & Auction & Total \\
\hline \multirow[t]{6}{*}{ IPO year } & 1993 & 1 & 1 & 2 \\
\hline & 1994 & 11 & 11 & 22 \\
\hline & 1995 & 1 & 8 & 9 \\
\hline & 1996 & 19 & 23 & 42 \\
\hline & 1997 & 30 & 21 & 51 \\
\hline & 1998 & 52 & 26 & 78 \\
\hline \multirow[t]{2}{*}{ Exchange } & Second Marché & 53 & 90 & 143 \\
\hline & Nouveau Marché & 61 & 0 & 61 \\
\hline \multirow[t]{20}{*}{ Industry } & Mechanical engineering & 4 & 3 & 7 \\
\hline & Intermediate goods & 3 & 5 & 8 \\
\hline & Other capital goods & 3 & 3 & 6 \\
\hline & Automotive & 2 & 7 & 9 \\
\hline & Household/Professional goods & 8 & 8 & 16 \\
\hline & Pharmaceuticals/Cosmetics & 7 & 7 & 14 \\
\hline & Opticals & 1 & 1 & 2 \\
\hline & Textile & 5 & 2 & 7 \\
\hline & Beverages & 5 & 2 & 7 \\
\hline & Other agrifood & 6 & 2 & 8 \\
\hline & Electricity/Electronics/Telecommunication & 11 & 6 & 17 \\
\hline & Information technology & 19 & 10 & 29 \\
\hline & Communication/Advertising/Broadcasting & 6 & 7 & 13 \\
\hline & Consumer retailing & 11 & 9 & 20 \\
\hline & Sport/Entertainment & 4 & 2 & 6 \\
\hline & Transport/Storage & 3 & 2 & 5 \\
\hline & Environment/Collective services & 8 & 5 & 13 \\
\hline & Sales to business & 1 & 4 & 5 \\
\hline & Hotels/Catering/Tourism & 4 & 4 & 8 \\
\hline & Insurance & 3 & 1 & 4 \\
\hline
\end{tabular}


Panel B: Lead underwriters

\begin{tabular}{|c|c|c|c|}
\hline Underwriter's name & Book-building & Auction & \\
\hline ABN Amro & 2 & 0 & \\
\hline Aurel & 3 & 0 & \\
\hline BA Robertson Stephens International & 1 & 0 & \\
\hline Banque Française de Service et de Crédit & 0 & 2 & \\
\hline BNP & 7 & 7 & \\
\hline Banques Populaires & 4 & 33 & \\
\hline Banque CPR & 5 & 0 & \\
\hline Banque Colbert & 1 & 0 & \\
\hline Banque Scalbert-Dupont & 1 & 0 & \\
\hline Banque Worms & 2 & 2 & Recs not recorded in $\mathrm{I} / \mathrm{B} / \mathrm{E} / \mathrm{S}$ \\
\hline Banque d'Orsay & 0 & 4 & Recs not recorded in $\mathrm{I} / \mathrm{B} / \mathrm{E} / \mathrm{S}$ \\
\hline Banque de Neuflize, Schlumberger, Mallet & 1 & 0 & \\
\hline Banque de Vizille & 2 & 0 & \\
\hline Crédit Agricole & 10 & 10 & \\
\hline Caisse des Dépôts et Consignations & 3 & 0 & \\
\hline Crédit Industriel et Commercial & 5 & 7 & \\
\hline Crédit Lyonnais & 15 & 3 & \\
\hline Crédit National & 6 & 5 & \\
\hline Crédit Mutuel & 0 & 2 & \\
\hline Cyril Finance & 1 & 0 & Recs not recorded in $\mathrm{I} / \mathrm{B} / \mathrm{E} / \mathrm{S}$ \\
\hline Ferri & 4 & 0 & \\
\hline HSBC & 1 & 0 & \\
\hline Hambrecht \& Quist & 3 & 0 & \\
\hline Lazard & 2 & 0 & \\
\hline Lehman Brothers & 1 & 0 & \\
\hline Lyonnaise de banque & 0 & 1 & \\
\hline Merril Lynch & 1 & 0 & \\
\hline Natexis & 1 & 0 & \\
\hline Natwest & 1 & 0 & \\
\hline Nomura & 1 & 0 & \\
\hline Oddo & 2 & 0 & \\
\hline Paribas & 8 & 1 & \\
\hline Pinatton & 9 & 0 & \\
\hline Société Générale & 9 & 1 & \\
\hline SPEF Technology & 2 & 0 & \\
\hline
\end{tabular}




\section{Panel C: IPO characteristics}

\begin{tabular}{|c|c|c|c|}
\hline & & Book-building & Auction \\
\hline \multirow{6}{*}{ Market capitalization (in MFRF) } & Mean & 567 & 287 \\
\hline & Median & 263 & 187 \\
\hline & IQR & 431 & 161 \\
\hline & Min & 55 & 62 \\
\hline & Max & 6,138 & 1,356 \\
\hline & $\mathrm{N}$ & 114 & 90 \\
\hline \multirow{6}{*}{ Secondary shares } & Mean & $12.00 \%$ & $10.89 \%$ \\
\hline & Median & $10.14 \%$ & $10.00 \%$ \\
\hline & IQR & $15.80 \%$ & $4.38 \%$ \\
\hline & Min & 0 & 0 \\
\hline & Max & $56.09 \%$ & $27.64 \%$ \\
\hline & $\mathrm{N}$ & 114 & 90 \\
\hline \multirow{6}{*}{ Age } & Mean & 17.65 & 18.24 \\
\hline & Median & 10.00 & 15.00 \\
\hline & IQR & 14.00 & 16.00 \\
\hline & Min & 1.00 & 1.00 \\
\hline & Max & 124.00 & 61.00 \\
\hline & $\mathrm{N}$ & 98 & 86 \\
\hline \multirow{6}{*}{ Book-to-market } & Mean & 0.26 & 0.26 \\
\hline & Median & 0.17 & 0.22 \\
\hline & IQR & 0.25 & 0.17 \\
\hline & Min & -0.01 & 0.03 \\
\hline & Max & 1.16 & 0.76 \\
\hline & $\mathrm{N}$ & 111 & 90 \\
\hline \multirow{6}{*}{ Number of underwriters } & Mean & 2.08 & 1.79 \\
\hline & Median & 2.00 & 2.00 \\
\hline & IQR & 1.00 & 1.00 \\
\hline & Min & 1.00 & 1.00 \\
\hline & Max & 9.00 & 4.00 \\
\hline & $\mathrm{N}$ & 114 & 90 \\
\hline \multirow{6}{*}{ Underwriting fees } & Mean & $7.05 \%$ & $5.53 \%$ \\
\hline & Median & $6.76 \%$ & $4.80 \%$ \\
\hline & IQR & $4.84 \%$ & $7.26 \%$ \\
\hline & Min & $1.29 \%$ & $1.56 \%$ \\
\hline & Max & $17.14 \%$ & $12.90 \%$ \\
\hline & $\mathrm{N}$ & 78 & 11 \\
\hline \multirow{6}{*}{ Number of SEOs } & Mean & 0.51 & 0.28 \\
\hline & Median & 0.00 & 0.00 \\
\hline & IQR & 1.00 & 0.00 \\
\hline & Min & 0.00 & 0.00 \\
\hline & Max & 4.00 & 3.00 \\
\hline & $\mathrm{N}$ & 114 & 90 \\
\hline \multirow{6}{*}{ Initial return } & Mean & $20.57 \%$ & $15.93 \%$ \\
\hline & Median & $8.94 \%$ & $7.69 \%$ \\
\hline & IQR & $32.26 \%$ & $26.46 \%$ \\
\hline & Min & $-24.97 \%$ & $-38.21 \%$ \\
\hline & Max & $155.00 \%$ & $128.57 \%$ \\
\hline & $\mathrm{N}$ & 114 & 90 \\
\hline
\end{tabular}




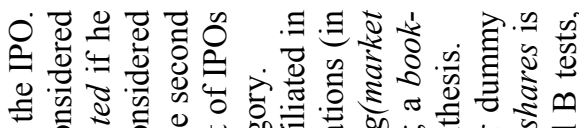

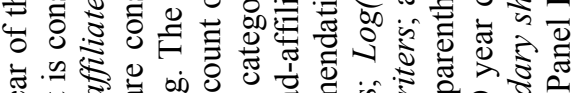

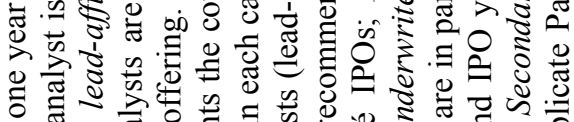

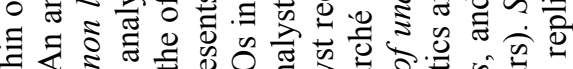

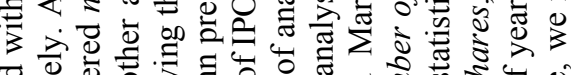

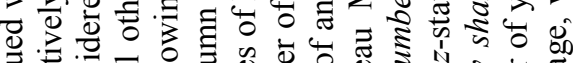

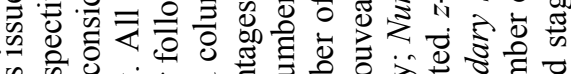

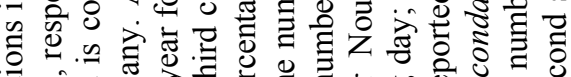

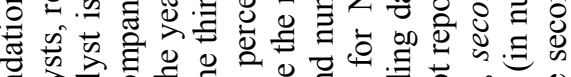

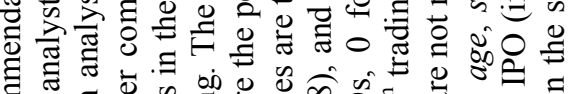

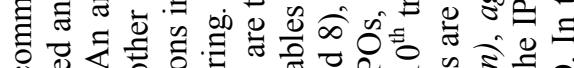

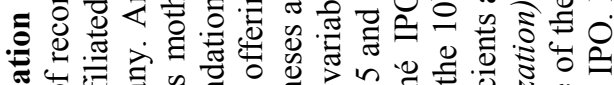

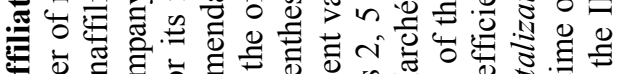

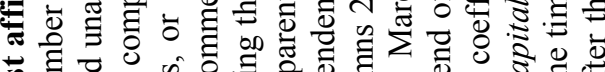
फ़

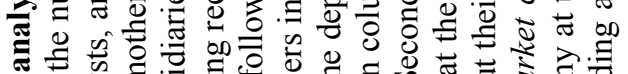

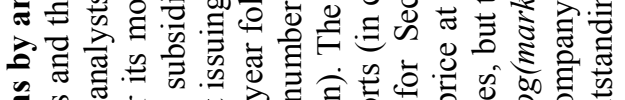

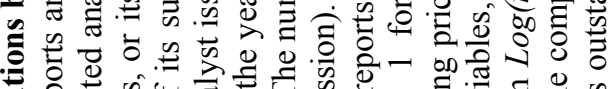

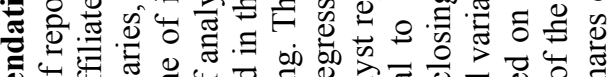

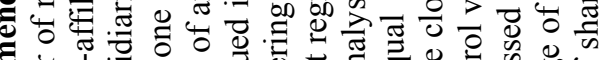

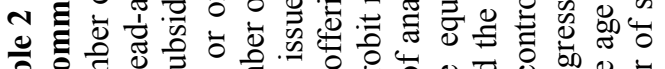

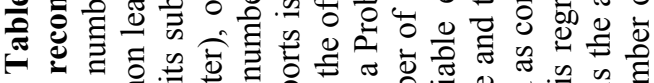

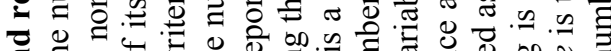

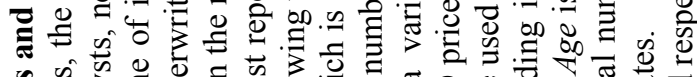

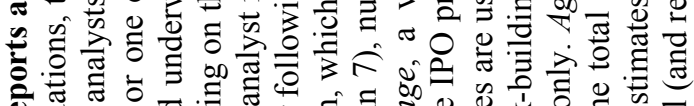

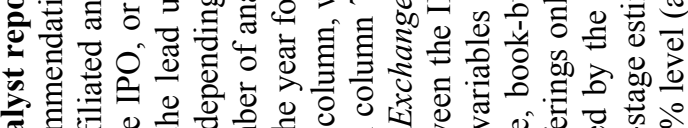

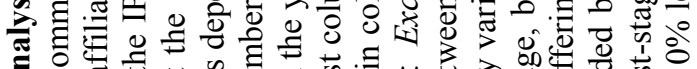

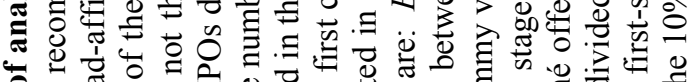

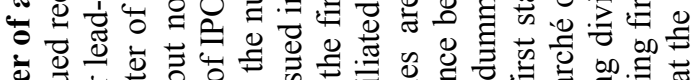

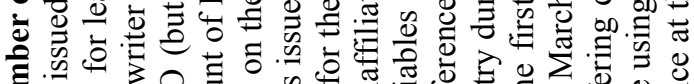

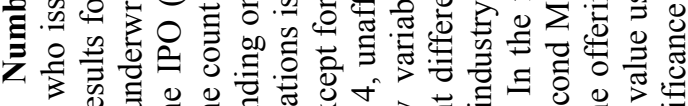

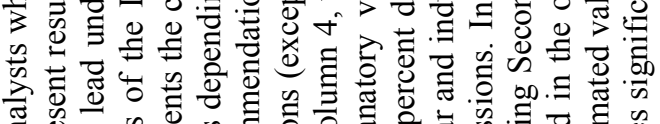

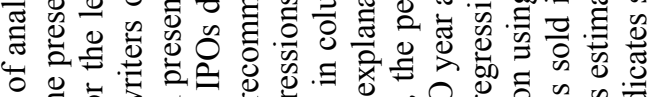

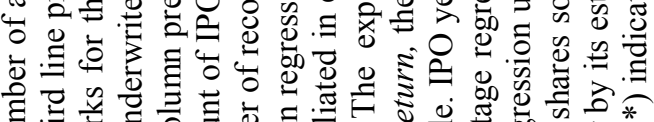

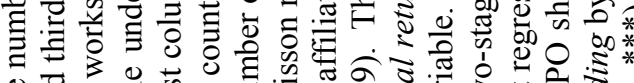

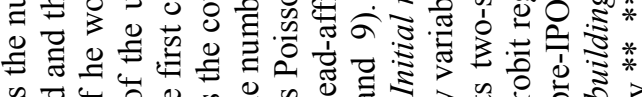

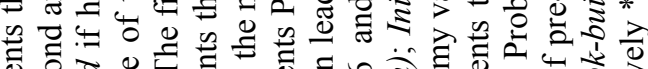

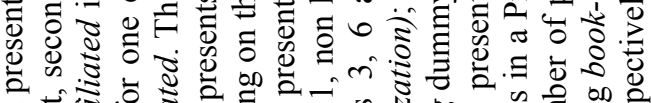

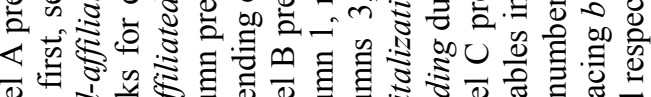

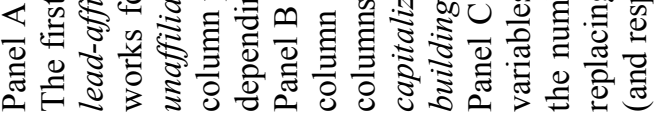

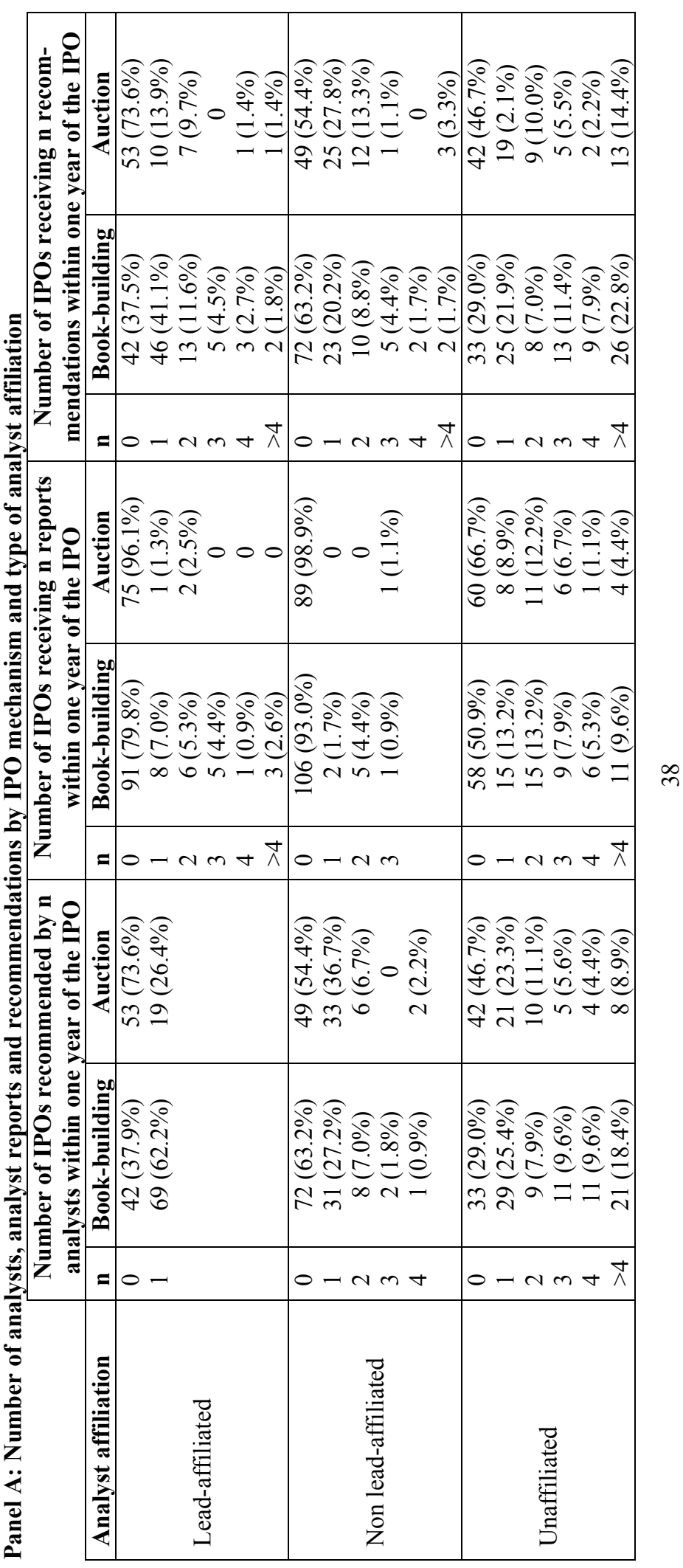




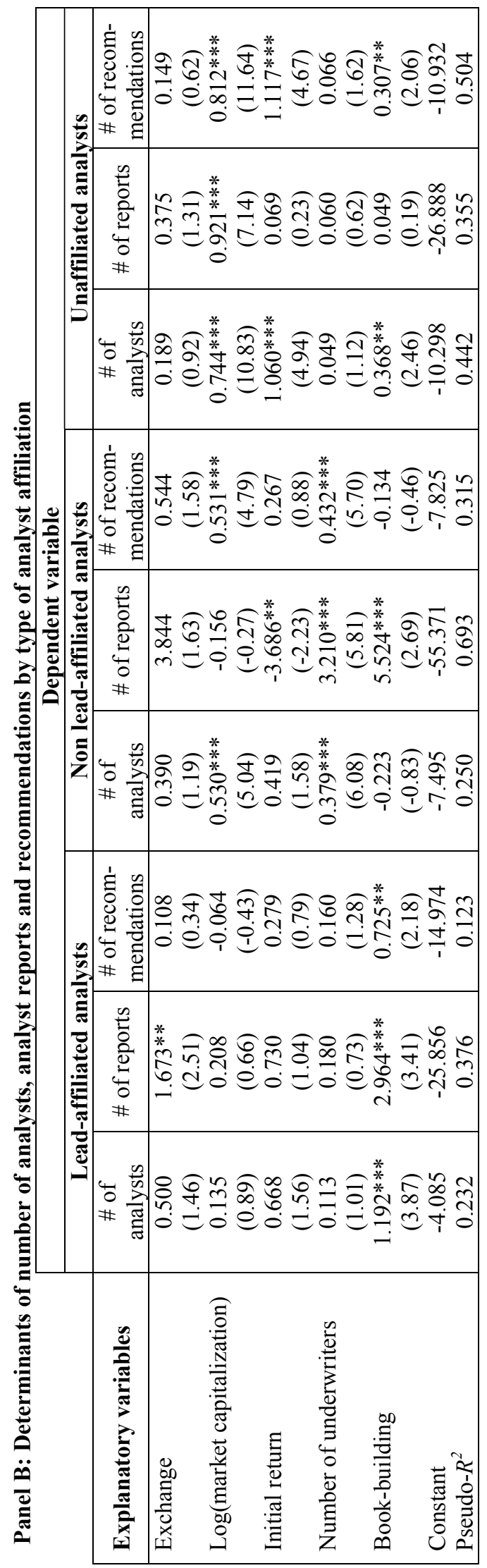




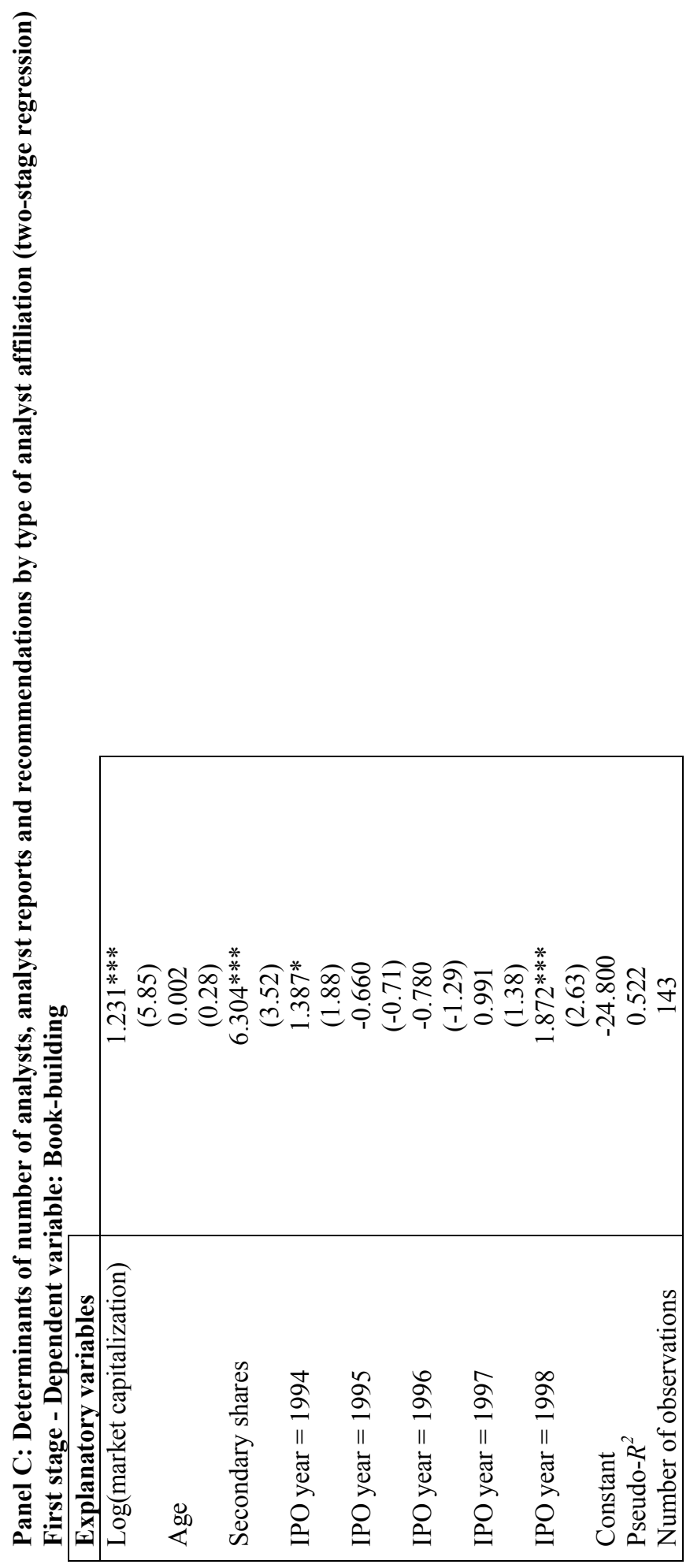

\begin{tabular}{|c|c|c|c|c|c|}
\hline & 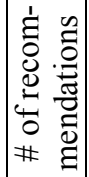 & \multicolumn{4}{|c|}{ 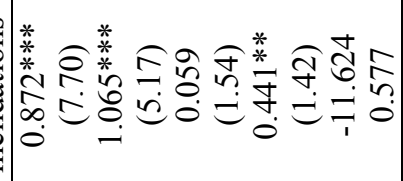 } \\
\hline & 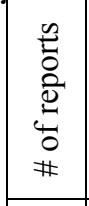 & \multicolumn{4}{|c|}{ 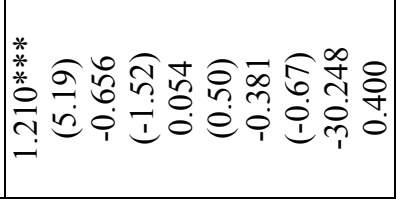 } \\
\hline & 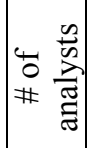 & \multicolumn{4}{|c|}{ 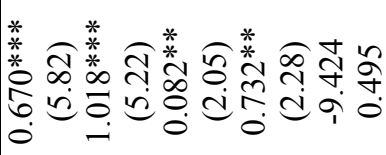 } \\
\hline & 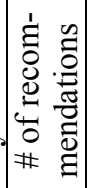 & \multicolumn{4}{|c|}{ 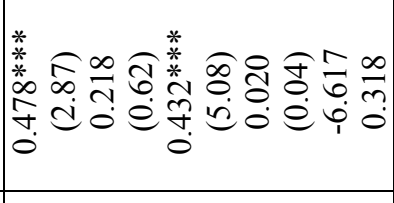 } \\
\hline$\frac{2}{5}$ & 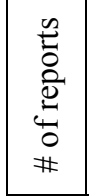 & \multicolumn{4}{|c|}{ 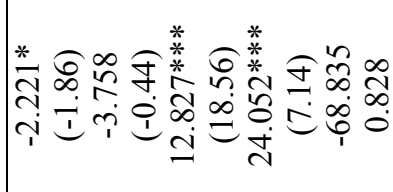 } \\
\hline & 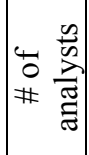 & \multicolumn{4}{|c|}{ 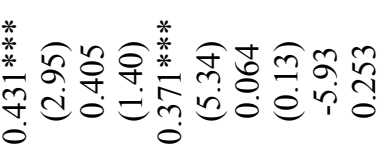 } \\
\hline & 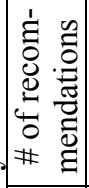 & \multicolumn{4}{|c|}{ 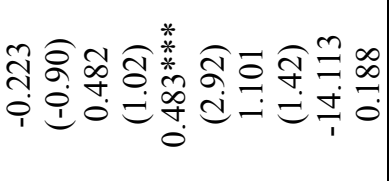 } \\
\hline 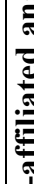 & 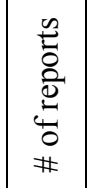 & \multicolumn{4}{|c|}{ 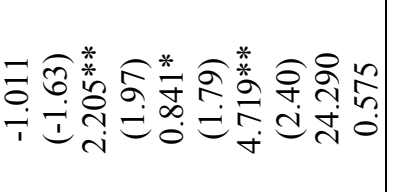 } \\
\hline & 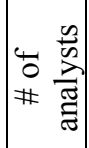 & \multicolumn{4}{|c|}{ 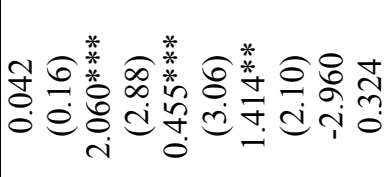 } \\
\hline & 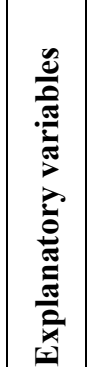 & 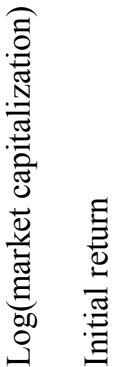 & 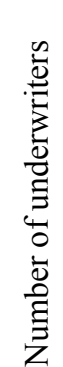 & 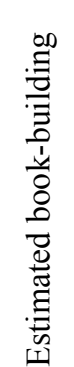 & 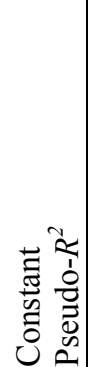 \\
\hline
\end{tabular}


Table 3

Type of analyst recommendations by analyst affiliation

Panel A presents the number of analyst recommendations within one year of the IPO by type of recommendation for book-buildings vs. auctions. Recommendations can be of 5 types: 1, 2, 3, 4, and 5 correspond to "strong buy", "buy", "hold", "underperform", and "sell", respectively. The number of recommendations of each type is reported for both IPO mechanisms by type of analyst affiliation. An analyst is considered lead-affiliated if he works for the lead underwriter of the IPO, or one of its subsidiaries, or its mother company. An analyst is considered non lead-affiliated if he works for one of the underwriters of the IPO (but not the lead underwriter), or one of its subsidiaries, or its mother company. All other analysts are considered unaffiliated. The number in parenthesis is the percentage of recommendations in the corresponding category.

Ordered Probit regressions appear in Panel B. Types of recommendations from lead-affiliated, non lead-affiliated and unaffiliated analysts are the dependent variables in columns 1, 2 and 3, respectively. For each recommendation, the type of recommendation is regressed against: Exchange, a variable equal to 1 for Second Marché IPOs, 0 for Nouveau Marché IPOs; Log(market capitalization); Initial return, the percent difference between the IPO price and the closing price at the end of the $10^{\text {th }}$ trading day; Number of underwriters; and a book-building dummy variable.

Panel C presents two-stage regressions. In the first stage, book-building is regressed on Log(market capitalization), age, secondary shares, and IPO year dummy variables in a Probit regression using Second Marché offerings only. Age is the age of the company at the time of the IPO (in number of years). Secondary shares is the number of pre-IPO shares sold in the offering divided by the total number of shares outstanding after the IPO. In the second stage, we replicate Panel B tests, replacing book-building by its estimated value using first-stage estimates.

$z$-statistics, calculated assuming independence across companies using Huber's robust variance estimator, are in parenthesis.

$*$ (and respectively $* *, * * *$ ) indicates significance at the $10 \%$ level (and respectively at the $5 \%$ level, at the $1 \%$ level).

Panel A: Type of analyst recommendations by IPO mechanism and type of analyst affiliation

\begin{tabular}{|l|l|c|c|}
\hline Analyst affiliation & Type of recommendation & \# for book-buildings & \# for auctions \\
\hline \multirow{5}{*}{ Lead-affiliated } & 1 (strong buy) & $53(48.2 \%)$ & $11(33.3 \%)$ \\
& 2 (buy) & $37(33.6 \%)$ & $11(33.3 \%)$ \\
& 3 (hold) & $17(15.4 \%)$ & $8(24.2 \%)$ \\
& 4 (underperform) & $2(1.8 \%)$ & $3(9.1 \%)$ \\
& 5 (sell) & $1(0.9 \%)$ & 0 \\
\hline \multirow{5}{*}{ Non lead-affiliated } & 1 (strong buy) & $30(39.5 \%)$ & $24(33.8 \%)$ \\
& 2 (buy) & $34(44.7 \%)$ & $24(33.8 \%)$ \\
& 3 (hold) & $10(13.2 \%)$ & $3(26.8 \%)$ \\
& 4 (underperform) & $2(2.6 \%)$ & $1(1.4 \%)$ \\
\hline \multirow{5}{*}{ Unaffiliated } & 5 (sell) & $121(32.5 \%)$ & $57(31.1 \%)$ \\
& 1 (strong buy) & $137(36.8 \%)$ & $76(41.5 \%)$ \\
& 2 (buy) & $76(20.4 \%)$ & $33(18.0 \%)$ \\
& 3 (hold) & $30(8.1 \%)$ & $14(7.6 \%)$ \\
& 4 (underperform) & $8(2.1 \%)$ & $3(1.6 \%)$ \\
\hline
\end{tabular}


Panel B: Determinants of analysts recommendations by type of analyst affiliation

\begin{tabular}{|c|c|c|c|}
\hline & Depe & riable: Recommend & by \\
\hline Explanatory variables & Lead-affiliated & Non lead-affiliated & Unaffiliated \\
\hline Exchange & $\begin{array}{c}-0.582 * * \\
(-218)\end{array}$ & 0.260 & -0.075 \\
\hline Log(market capitalization) & $0.195 *$ & 0.136 & -0.010 \\
\hline & $(1.78)$ & $(1.13)$ & $(-0.21)$ \\
\hline Initial return & 0.349 & -0.204 & -0.036 \\
\hline & $(0.94)$ & $(-0.91)$ & $(-0.27)$ \\
\hline Number of underwriters & -0.027 & -0.039 & -0.041 \\
\hline & $(-0.37)$ & $(-0.86)$ & $(-1.03)$ \\
\hline Book-building & $-0.812 * * *$ & $-0.303 *$ & 0.015 \\
\hline & $(-3.00)$ & $(-1.67)$ & $(0.14)$ \\
\hline Pseudo- $R^{2}$ & 0.035 & 0.018 & 0.002 \\
\hline Number of observations & 143 & 147 & 555 \\
\hline
\end{tabular}

Panel C: Determinants of analysts recommendations by type of analyst affiliation (second stage of two-stage regressions)

\begin{tabular}{|l|c|c|c|}
\cline { 2 - 4 } \multicolumn{1}{c|}{} & \multicolumn{2}{c|}{ Dependent variable: Recommendation type by } \\
\hline Explanatory variables & Lead-affiliated & Non lead-affiliated & Unaffiliated \\
\hline Log(market capitalization) & $0.511^{* * *}$ & 0.163 & -0.006 \\
Initial return & $(3.05)$ & $-0.10)$ \\
& -0.539 & -0.005 & -0.105 \\
Number of underwriters & $(-0.97)$ & $(-0.02)$ & $(-0.83)$ \\
& 0.051 & -0.056 & -0.025 \\
Estimated book-building & $(0.60)$ & $(-1.34)$ & $(-0.51)$ \\
& $-1.702^{* * *}$ & -0.328 & -0.038 \\
Pseudo- $R^{2}$ & $(-3.80)$ & $(-1.36)$ & $(-0.24)$ \\
Number of observations & 0.077 & 0.006 & 0.001 \\
\hline
\end{tabular}


Table 4

Analyst recommendations and past stock price performance

Panel A presents the number and average type of analyst recommendations within one year of the IPO by type of analyst affiliation for book-buildings vs. auctions, depending on past performance. Recommendations can be of 5 types: 1, 2, 3, 4, and 5 correspond to "strong buy", "buy", "hold", "underperform", and "sell", respectively. An analyst is considered lead-affiliated if he works for the lead underwriter of the IPO, or one of its subsidiaries, or its mother company. An analyst is considered non lead-affiliated if he works for one of the underwriters of the IPO (but not the lead underwriter), or one of its subsidiaries, or its mother company. All other analysts are considered unaffiliated. Past performance is the average daily buy-and-hold return adjusted using size/book-to-market portfolios between the IPO date and the recommendation date minus two days. This variable is divided into thirds, and each analyst recommendation is assigned to one third. The number in parentheses is the percentage of recommendations in the corresponding category.

Ordered Probit regressions appear in Panel B. For each analyst recommendation, the type of recommendation is the dependent variable. Book-built IPOs are in column 1, auctions in column 2. The independent variables are: Exchange, a variable equal to 1 for Second Marché IPOs, 0 for Nouveau Marché IPOs; Log(market capitalization); Lead-affiliated, a variable equal to one if the analyst is lead-affiliated, 0 otherwise; and two interaction variables obtained by multiplying Lead-affiliated and 1-Leadaffiliated by 1 if past performance is negative, 0 otherwise.

Panel C presents Poisson regressions. The dependent variable is the number of positive recommendations (type 1, "strong buy", or 2, "buy") from lead-affiliated analysts for a given firm/month. The explanatory variables are Exchange; Log(market capitalization); Months since IPO, the number of months between the IPO date and the beginning of the month considered; Performance change, equal to 1 in a month when the stock's cumulative adjusted price performance had been positive since the IPO but turned negative in the prior month.

$z$-statistics, calculated assuming independence across companies using Huber's robust variance estimator, are in parenthesis. Coefficients with an "a" (and, respectively, with a "b", a "c") in superscript are significantly different from each other at the $1 \%$ level (and, respectively, at the 5\% level, at the $10 \%$ level).

* (and respectively **,***) indicates significance at the $10 \%$ level (and respectively at the $5 \%$ level, at the $1 \%$ level).

Panel A: Analyst recommendations by IPO mechanism and type of analyst affiliation depending on past performance

\begin{tabular}{|l|l|c|c|c|c|}
\cline { 3 - 6 } \multicolumn{2}{c|}{} & \multicolumn{2}{c|}{ Book-building } & \multicolumn{2}{c|}{ Auction } \\
\hline \multirow{2}{*}{ Analyst affiliation } & $\begin{array}{l}\text { Third of past } \\
\text { performance }\end{array}$ & $\begin{array}{c}\text { Number of } \\
\text { recommendations }\end{array}$ & $\begin{array}{c}\text { Average type of } \\
\text { recommendations }\end{array}$ & $\begin{array}{c}\text { Number of } \\
\text { recommendations }\end{array}$ & $\begin{array}{c}\text { Average type of } \\
\text { recommendations }\end{array}$ \\
\hline \multirow{3}{*}{ Lead-affiliated } & 1 (bottom) & $50(47.2 \%)$ & 1.64 & $13(39.4 \%)$ & 2.23 \\
& 2 (middle) & $32(30.2 \%)$ & 1.75 & $6(18.2 \%)$ & 2.17 \\
& 3 (top) & $24(22.6 \%)$ & 1.96 & $14(42.4 \%)$ & 1.93 \\
\hline \multirow{3}{*}{ Non lead-affiliated } & 1 (bottom) & $28(38.4 \%)$ & 1.96 & $26(37.7 \%)$ & 1.88 \\
& 2 (middle) & $19(26.0 \%)$ & 1.74 & $17(24.6 \%)$ & 2.18 \\
& 3 (top) & $26(35.6 \%)$ & 1.69 & $26(37.7 \%)$ & 2.23 \\
\hline \multirow{3}{*}{ Unaffiliated } & 1 (bottom) & $123(34.4 \%)$ & 2.33 & $31(17.7 \%)$ & 2.19 \\
& 2 (middle) & $132(37.0 \%)$ & 1.99 & $65(37.1 \%)$ & 2.17 \\
& 3 (top) & $102(28.6 \%)$ & 2.02 & $79(45.1 \%)$ & 2.00 \\
\hline
\end{tabular}


Panel B: Determinants of analysts recommendations - Ordered probit coefficients

\begin{tabular}{|l|c|c|}
\cline { 2 - 3 } \multicolumn{1}{c|}{} & \multicolumn{2}{c|}{ Dependent variable: Type of recommendation } \\
\hline Explanatory variables & Book-building & Auction \\
Log(market capitalization) & -0.153 & -- \\
& $(-0.94)$ & 0.057 \\
Lead-affiliated & 0.054 & $(0.62)$ \\
& $(0.94)$ & -0.181 \\
Lead-affiliated * negative past performance & -0.165 & $(-0.66)$ \\
& $(-1.09)$ & $0.689^{*} * \mathrm{c}$ \\
(1-Lead-affiliated) * negative past performance & $-0.279^{\mathrm{a}}$ & $(2.00)$ \\
& $(-1.26)$ & $-0.068^{\mathrm{c}}$ \\
Pseudo- $R^{2}$ & $0.459^{* * * a}$ & $(-0.33)$ \\
Number of observations & $(3.45)$ & 0.004 \\
\hline
\end{tabular}

Panel C: Determinants of the monthly number of positive ("buy" or "strong buy") recommendations from lead-affiliated analysts - Poisson regression coefficients

\begin{tabular}{|l|c|c|}
\cline { 2 - 3 } \multicolumn{1}{c|}{} & $\begin{array}{c}\text { Dependent variable: Number of positive recommendations } \\
\text { from lead-affiliated analysts for this firm/month }\end{array}$ \\
\hline Explanatory variables & Book-building & Auction \\
Log(market capitalization) & 0.353 & -- \\
& $(1.15)$ & -0.036 \\
Months since IPO & -0.045 & $(-0.09)$ \\
& $(-0.36)$ & $-0.238^{* * *}$ \\
Performance change & -0.048 & $(-2.77)$ \\
& $(-1.19)$ & 0.031 \\
Constant & $0.708^{* *}$ & $(0.03)$ \\
Number of observations & $(2.15)$ & -1.794 \\
\hline
\end{tabular}


Table 5

Tests of the "currying favor" hypothesis

Panel A presents the average number of positive recommendations (type 1, "strong buy", or 2, "buy") from unaffiliated analysts for a given firm/month, depending on past performance of the company and whether the underwriter of the IPO is underwriting another IPO between the beginning of this month and the end of next month. An analyst is considered unaffiliated if he does not work for any of the IPO underwriters. Past performance is the average monthly buy-and-hold return adjusted using size/bookto-market portfolios between the IPO date and the beginning of the month considered. This variable is divided into thirds, and each firm/month pair is assigned to one of the thirds. In the first line of Panel A, we consider only book-built IPOs, and break down the sample of firm/month pairs depending on whether the lead underwriter of the IPO is underwriting another book-built IPO in the next month. In the second line of Panel A, we consider auctioned IPOs, and separate the sample of firm/month pairs depending on whether the lead underwriter of the IPO is underwriting another IPO (auctioned or book-built) in the next month. An "a" (and, respectively, a "b") in superscript indicates significant difference between column-2 and column-4 numbers at the $1 \%$ level (and, respectively, at the $5 \%$ level) in tests of equality of means with unequal variance.

Panel B presents Poisson regressions, in which the dependent variable is the number of positive recommendations for a given firm/month pair from unaffiliated analysts for all firm/month pairs (columns 1 and 2) and for firm/month pairs in the bottom third of past performance (columns 3 and 4). The explanatory variables are Exchange; Log(market capitalization); Months since IPO, the number of months between the IPO date and the beginning of the month considered; Past performance; and New $I P O$ in the next month, equal to 1 if the lead underwriter of the IPO is underwriting another IPO in the next month, 0 otherwise. $z$-statistics, calculated assuming independence across companies using Huber's robust variance estimator, are in parentheses.

$*$ (and respectively $* *, * * *$ ) indicates significance at the $10 \%$ level (and respectively at the $5 \%$ level, at the $1 \%$ level).

Panel A: Number of unaffiliated analyst positive recommendations per month depending on past performance and whether the underwriter is underwriting another IPO in the next month

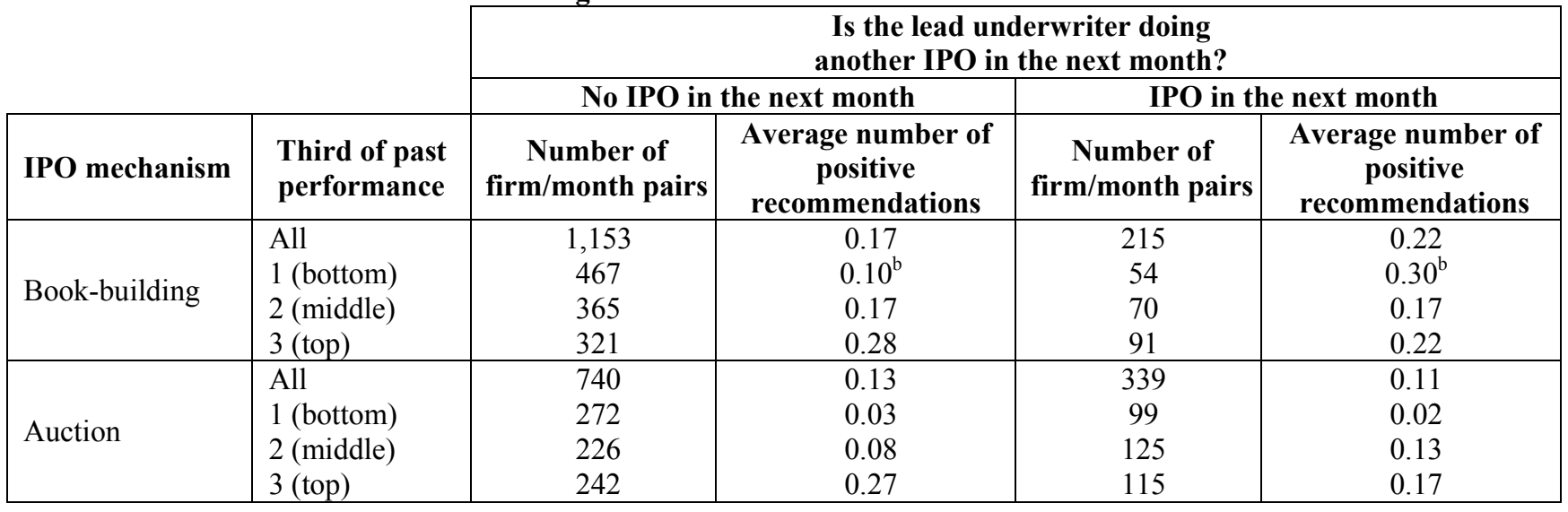

Panel B: Determinants of the monthly number of positive recommendations from unaffiliated analysts

\begin{tabular}{|l|c|c|c|c|}
\hline $\begin{array}{l}\text { Dependent variable: Number of positive } \\
\text { recommendations this month }\end{array}$ & \multicolumn{2}{|c|}{ All firm/month pairs } & \multicolumn{2}{c|}{$\begin{array}{c}\text { Firm/month pairs in the bottom } \\
\text { third of past performance }\end{array}$} \\
\hline Explanatory variables & Book-building & Auction & Book-building & Auction \\
\hline Exchange & 0.123 & -- & 0.152 & -- \\
& $(0.73)$ & & $(0.54)$ & $1.898^{* * *}$ \\
Log(market capitalization) & $0.822^{* * *}$ & $1.437 * * *$ & $0.840^{* * *}$ & $(2.65)$ \\
& $(13.66)$ & $(11.69)$ & $(8.13)$ & -0.037 \\
Months since IPO & 0.007 & $-0.094^{* *}$ & -0.005 & $(-0.35)$ \\
Past performance & $(0.34)$ & $(-2.08)$ & $(-0.14)$ & 0.375 \\
& $0.454^{* * *}$ & $0.858^{* * *}$ & $0.915^{* * *}$ & $(0.31)$ \\
New IPO in the next month & $(9.95)$ & $(8.81)$ & $(2.80)$ & -0.107 \\
Constant & $0.303 *$ & -0.110 & $0.427 * *$ & $(-0.14)$ \\
Number of observations & $(1.86)$ & $(-0.48)$ & $-2.25)$ & -26.933 \\
\hline
\end{tabular}


Table 6

Press coverage for book-built vs. auctioned IPOs

Panel A presents the count of IPOs depending on the number of newspaper articles written about the company within one year of the IPO, between IPO date minus 3 months and IPO date, and between IPO date minus 6 months and IPO date minus 3 months (the percentage out of the total number of each IPO type is in parenthesis).

Panel B presents Poisson regressions. The dependent variables are the number of newspaper articles written within one year of the IPO (column 1), between IPO date minus 3 months and IPO date (column 2), and between IPO date minus 6 months and IPO date minus 3 months (column 3). The explanatory variables are: Exchange, a variable equal to 1 for Second Marché IPOs, 0 for Nouveau Marché IPOs; Log(market capitalization); Initial return, the percent difference between the IPO price and the closing price at the end of the $10^{\text {th }}$ trading day; and a book-building dummy variable. IPO year and industry dummy variables are also used as control variables, but their coefficients are not reported. $z$-statistics are in parenthesis.

$*$ (and respectively **,***) indicates significance at the $10 \%$ level (and respectively at the $5 \%$ level, at the $1 \%$ level).

Panel A: Number of newspaper articles by IPO mechanism

\begin{tabular}{|l|l|c|c|}
\cline { 2 - 4 } \multicolumn{1}{c|}{} & \multicolumn{3}{c|}{ Number of IPOs receiving n newspaper articles } \\
\hline Period & 0 to 5 & $13(11.4 \%)$ & Auction \\
IPO date to IPO date +1 year & 6 to 10 & $17(14.9 \%)$ & $26(28.9 \%)$ \\
& 11 to 20 & $35(30.7 \%)$ & $23(25.6 \%)$ \\
& 21 to 30 & $20(17.5 \%)$ & $18(20.0 \%)$ \\
& $>30$ & $29(25.4 \%)$ & $6(18.9 \%)$ \\
IPO date -3 months to IPO date & 0 to 5 & $30(26.3 \%)$ & $58(64.4 \%)$ \\
& 6 to 10 & $39(34.2 \%)$ & $25(27.8 \%)$ \\
& 11 to 20 & $35(30.7 \%)$ & $7(7.8 \%)$ \\
IPO date -6 months to IPO date -3 months & $>20$ & $10(8.8 \%)$ & 0 \\
& 0 & $80(70.2 \%)$ & $56(62.2 \%)$ \\
& $>3$ & $23(20.2 \%)$ & $27(30.0 \%)$ \\
\end{tabular}

Panel B: Determinants of number of newspaper articles

\begin{tabular}{|l|c|c|c|}
\cline { 2 - 4 } \multicolumn{1}{c|}{ Explanatory variables } & \multicolumn{3}{c|}{ Dependent variable: Number of newspaper articles } \\
\hline Exchange & $\begin{array}{c}\text { IPO date to IPO date } \\
+\mathbf{1} \text { year }\end{array}$ & $\begin{array}{c}\text { IPO date - 3 months } \\
\text { to IPO date }\end{array}$ & $\begin{array}{c}\text { IPO date - 6 months to } \\
\text { IPO date - 3 months }\end{array}$ \\
Log(market capitalization) & -0.091 & -0.209 & -0.170 \\
& $(-0.55)$ & $(-1.32)$ & $(-0.37)$ \\
Initial return & $0.487 * *$ & $0.332 * * *$ & $0.763 * * *$ \\
& $(6.61)$ & $(4.20)$ & $(4.19)$ \\
Book-building & -0.005 & -- & -- \\
Constant & $(-0.04)$ & $0.409 * * *$ & -0.373 \\
Pseudo- $R^{2}$ & $0.324 * *$ & $(3.15)$ & $(-0.81)$ \\
& $(2.38)$ & -3.049 & -9.099 \\
\hline
\end{tabular}


Table 7

Stock price reaction and one-year stock price performance following positive analyst recommendations Panel A presents the mean and median immediate stock price reactions to positive recommendations (type 1, "strong buy", or 2, "buy") for the three types of analyst affiliation. Stock price reaction is the buy-and-hold return adjusted using size/book-to-market portfolios between recommendation date minus 1 day and recommendation date plus 1 day. An analyst is considered lead-affiliated if he works for the lead underwriter of the IPO, or one of its subsidiaries, or its mother company. An analyst is considered non lead-affiliated if he works for one of the underwriters of the IPO (but not the lead underwriter), or one of its subsidiaries, or its mother company. All other analysts are considered unaffiliated.

Panel B presents the mean and median of immediate stock price reaction to positive recommendations by leadaffiliated analysts only, depending on past stock price performance. Past performance is the average daily buy-andhold return adjusted using size/book-to-market portfolios between IPO date and recommendation date minus 2 days. This variable is divided into thirds, and each recommendation is assigned to one third. An "a" (and, respectively, a "b", a "c") in superscript indicates significant difference between numbers at the $1 \%$ level (and, respectively, at the $5 \%$ level, at the $10 \%$ level) in tests of equality of means with unequal variance.

Panel $\mathrm{C}$ presents the mean and median of 12-month stock price performance following positive recommendations, by type of analyst affiliation. Stock price performance is the buy-and-hold return adjusted using size/book-to-market portfolios between recommendation date plus 2 days and recommendation date plus 2 days plus twelve months.

Panel D presents OLS regressions of 12-month stock price performance following recommendations against the following variables, for the three types of analyst affiliation: Exchange, a variable equal to 1 for Second Marché IPOs, 0 for Nouveau Marché IPOs; Log(market capitalization); Past performance; and a book-building dummy variable. IPO year and industry dummy variables are used as control variables, but their coefficients are not reported. $z$-statistics, calculated assuming independence across companies using Huber's robust variance estimator, are in parenthesis.

* (and respectively $* *, * * *$ ) indicates significance at the $10 \%$ level (and respectively at the $5 \%$ level, at the $1 \%$ level).

Panel A: Stock price reaction to positive recommendations by analyst affiliation

\begin{tabular}{|l|l|c|c|}
\hline Analyst affiliation & & Book-building & Auction \\
\hline \multirow{3}{*}{ Lead-affiliated } & Mean & $1.12 \%$ & $1.10 \%$ \\
& Median & $0.07 \%$ & $1.20 \%$ \\
& \# of recommendations & 88 & 22 \\
\hline \multirow{3}{*}{ Non lead-affiliated } & Mean & $1.57 \% *$ & $-0.67 \%$ \\
& Median & $1.12 \% *$ & $-0.51 \%$ \\
& \# of recommendations & 61 & 46 \\
\hline \multirow{3}{*}{ Unaffiliated } & Mean & $0.28 \%$ & $0.88 \% * *$ \\
& Median & $-0.37 \%$ & $0.44 \%$ \\
& \# of recommendations & 245 & 130 \\
\hline
\end{tabular}

Panel B: Stock price reaction to positive recommendations depending on past performance (leadaffiliated analysts only)

\begin{tabular}{|l|l|c|c|}
\hline $\begin{array}{l}\text { Third of past } \\
\text { performance }\end{array}$ & Book-building & Auction \\
\hline \multirow{3}{*}{1 (bottom) } & Mean & $-0.65 \% \%^{\mathrm{b}}$ & $-1.13 \%$ \\
& Median & $-0.62 \%^{\mathrm{c}}$ & $1.18 \%$ \\
\hline \multirow{3}{*}{ (middle) } & \# of recommendations & 43 & 7 \\
\hline \multirow{3}{*}{3 (top) } & Mean & $1.18 \%$ & $4.30 \%$ \\
& Median & $0.26 \%$ & $4.35 \%$ \\
& \# of recommendations & 26 & 4 \\
\hline & Mean & $5.79 \% \%^{\mathrm{b}}$ & $1.34 \%$ \\
& Median & $1.95 \%{ }^{\mathrm{c}}$ & $-0.43 \%$ \\
\hline
\end{tabular}


Panel C: 12-month stock price performance following positive recommendations by analyst affiliation

\begin{tabular}{|l|l|c|c|}
\hline Analyst affiliation & & Book-building & Auction \\
\hline \multirow{3}{*}{ Lead-affiliated } & Mean & $-5.02 \%$ & $2.22 \%$ \\
& Median & $-13.67 \% * *$ & $-21.91 \%$ \\
& \# of recommendations & 89 & 22 \\
\hline \multirow{3}{*}{ Non lead-affiliated } & Mean & $-6.27 \%$ & $-5.81 \%$ \\
& Median & $-19.85 \% *$ & $-22.67 \%$ \\
\hline \multirow{3}{*}{ Unaffiliated } & \# of recommendations & 63 & 48 \\
& Mean & $2.61 \%$ & $-0.31 \%$ \\
& Median & $-9.20 \% * *$ & $-0.26 \%$ \\
\hline
\end{tabular}

Panel D: Determinants of 12-month performance following positive recommendations by type of analyst affiliation

\begin{tabular}{|c|c|c|c|}
\hline \multirow[b]{2}{*}{ Explanatory variables } & \multicolumn{3}{|c|}{ Dependent variable: 12-month stock price performance } \\
\hline & Lead-affiliated & Non lead-affiliated & Unaffiliated \\
\hline Exchange & $\begin{array}{c}-0.517^{*} \\
(-1.73)\end{array}$ & $\begin{array}{l}0.036 \\
(0.14)\end{array}$ & $\begin{array}{l}-0.420 \\
(-1.45)\end{array}$ \\
\hline $\log$ (market capitalization) & $\begin{array}{c}0.215^{*} \\
(1.84)\end{array}$ & $\begin{array}{l}-0.080 \\
(-0.83)\end{array}$ & $\begin{array}{l}0.070 \\
(0.93)\end{array}$ \\
\hline Past performance & $\begin{array}{l}6.752 \\
(0.28)\end{array}$ & $\begin{array}{l}-4.242 \\
(-0.65)\end{array}$ & $\begin{array}{l}6.641 \\
(1.15)\end{array}$ \\
\hline Book-building & $\begin{array}{c}-0.392 * * \\
(-2.16)\end{array}$ & $\begin{array}{l}0.0033 \\
(0.19)\end{array}$ & $\begin{array}{c}-0.345^{*} \\
(-1.88)\end{array}$ \\
\hline$R^{2}$ & 0.322 & 0.392 & 0.228 \\
\hline Number of observations & 107 & 107 & 365 \\
\hline
\end{tabular}


Table 8

Offer price, liquidity, and probability of doing SEOs for book-built vs. auctioned IPOs

Panel A present regressions (OLS in all columns except column 5, where the dependent variable is Number of SEOs and Poisson regression is used). The dependent variables are book-to-market, where market capitalization is calculated at the end of the $10^{\text {th }}$ trading day; One-year performance, calculated from the $10^{\text {th }}$ trading day after the IPO as as a buy-and-hold return adjusted using size and book-to-market portfolios; $\log$ (volume), equal to the natural logarithm of average daily trading volume in the year following the IPO; $\log$ (Turnover), the natural logarithm of average daily trading volume divided by the float at IPO date; $\log$ (spread), the average bid-ask spread (in percent of the mid-price) in the year following the IPO; Number of SEOs, the number of Seasoned Equity Offerings in the five-year period following the IPO; and $\log$ (amount raised), the natural logarithm of the total amount raised in equity in the five-year period following the IPO, for firms with at least one SEO in this period. The independent variables are: Exchange, a variable equal to 1 for Second Marché IPOs, 0 for Nouveau Marché IPOs; Log(market capitalization); Initial return, the percent difference between the IPO price and the closing price at the end of the $10^{\text {th }}$ trading day; and a book-building dummy variable. IPO year and industry dummy variables are used as control variables, but their coefficients are not reported.

Panel B presents two-stage regressions. The first stage is similar to the first stage of the 2SLS regression in Table 2, Panel C. In the second stage, we replicate Panel A tests, replacing book-building by its estimated value using first-stage estimates. $t$-statistics are in parenthesis.

* (and respectively **,***) indicates significance at the $10 \%$ level (and respectively at the 5\% level, at the $1 \%$ level).

Panel A: OLS analysis

\begin{tabular}{|l|c|c|c|c|c|c|c|}
\cline { 2 - 7 } \multicolumn{1}{c|}{ Explanatory variables } & $\begin{array}{c}\text { Book-to- } \\
\text { market }\end{array}$ & $\begin{array}{c}\text { One-year } \\
\text { performance }\end{array}$ & Log(volume) & Log(turnover) & Log(spread) & $\begin{array}{c}\text { Number of } \\
\text { SEOs }\end{array}$ & $\begin{array}{c}\text { Log(amount } \\
\text { raised) }\end{array}$ \\
\hline Exchange & $0.164 * * *$ & -0.117 & -0.215 & -0.082 & 0.119 & $-1.042^{* *}$ & 0.772 \\
Log(market & $(4.24)$ & $(-0.82)$ & $(-1.01)$ & $(-0.44)$ & $(1.10)$ & $(-2.00)$ & $(1.04)$ \\
capitalization) & 0.008 & -0.015 & $0.952 * * *$ & 0.080 & $-0.264 * * *$ & -0.038 & $0.890^{* * *}$ \\
Initial return & $(0.59)$ & $(-0.25)$ & $(10.10)$ & $(0.87)$ & $(-6.26)$ & $(-0.24)$ & $(2.80)$ \\
& -- & $0.317 *$ & $1.219 * * *$ & $1.364 * *$ & $-0.513 * * *$ & $0.510^{*}$ & -0.359 \\
Book-building & & $(1.69)$ & $(5.61)$ & $(5.28)$ & $(-4.73)$ & $(1.79)$ & $(-0.80)$ \\
& $0.092^{* *}$ & -0.066 & $0.346^{*}$ & -0.266 & 0.122 & -0.262 & 1.166 \\
Constant & $(2.41)$ & $(-0.52)$ & $(1.88)$ & $(-1.62)$ & $(1.33)$ & $(-0.49)$ & $(1.47)$ \\
$R^{2}$ & -0.179 & 0.278 & -8.062 & -0.477 & -1.095 & -14.529 & 4.379 \\
Number of observations & 0.168 & 0.273 & 0.749 & 0.470 & 0.577 & 0.193 & 0.622 \\
\end{tabular}

Panel B: two-stage least squares (second-stage regression)

\begin{tabular}{|c|c|c|c|c|c|c|c|}
\hline \multirow[b]{2}{*}{ Explanatory variables } & \multicolumn{7}{|c|}{ Dependent variable } \\
\hline & $\begin{array}{c}\text { Book-to- } \\
\text { market }\end{array}$ & $\begin{array}{c}\text { One-year } \\
\text { performance }\end{array}$ & Log(volume) & Log(turnover) & $\log ($ spread $)$ & $\begin{array}{c}\text { Number of } \\
\text { SEOs }\end{array}$ & $\begin{array}{c}\text { Log(amount } \\
\text { raised) }\end{array}$ \\
\hline $\begin{array}{l}\text { Log(market } \\
\text { capitalization) }\end{array}$ & $\begin{array}{l}0.019 \\
(0.50)\end{array}$ & $\begin{array}{l}0.071 \\
(0.88)\end{array}$ & $\begin{array}{c}1.124 * * * \\
(5.52)\end{array}$ & $\begin{array}{l}0.352^{*} \\
(1.87)\end{array}$ & $\begin{array}{c}-0.239 * * * \\
(-2.82)\end{array}$ & $\begin{array}{l}-0.229 \\
(-0.66)\end{array}$ & $\begin{array}{l}1.065 \\
(1.24)\end{array}$ \\
\hline Initial return & -- & $\begin{array}{l}0.364^{*} \\
(1.79)\end{array}$ & $\begin{array}{c}1.279 * * * \\
(5.50)\end{array}$ & $\begin{array}{c}1.443 * * * \\
(7.21)\end{array}$ & $\begin{array}{c}-0.510 * * * \\
(-4.53)\end{array}$ & $\begin{array}{l}1.209 \\
(1.59)\end{array}$ & $\begin{array}{l}0.247 \\
(0.23)\end{array}$ \\
\hline Estimated book-building & $\begin{array}{l}0.087 \\
(0.73)\end{array}$ & $\begin{array}{l}-0.159 \\
(-0.68)\end{array}$ & $\begin{array}{l}0.089 \\
(0.15)\end{array}$ & $\begin{array}{c}-0.944 * \\
(-1.83)\end{array}$ & $\begin{array}{l}-0.008 \\
(-0.03)\end{array}$ & $\begin{array}{l}0.923 \\
(0.81)\end{array}$ & $\begin{array}{l}-0.320 \\
(-0.11)\end{array}$ \\
\hline Constant & -0.090 & -0.542 & -10.619 & -4.192 & -0.090 & -15.693 & 4.696 \\
\hline$R^{2}$ & 0.404 & 0.283 & 0.692 & 0.634 & 0.298 & 0.211 & 0.9155 \\
\hline Number of observations & 143 & 143 & 98 & 94 & 98 & 143 & 27 \\
\hline
\end{tabular}




\section{QUADERNI DELLA FACOLTÀ}

I quaderni sono richiedibili (nell'edizione a stampa) alla Biblioteca universitaria di Lugano via G. Buffi 13 CH 6900 Lugano

e-mail: biblioteca@lu.unisi.ch

The working papers (printed version) may be obtained by contacting the Biblioteca universitaria di Lugano via G. Buffi 13 CH 6900 Lugano

e-mail: $\underline{\text { biblioteca@lu.unisi.ch }}$

Quaderno n. 98-01

P. Balestra, Efficient (and parsimonious) estimation of structural dynamic error component models

Quaderno n. 99-01

M. Filippini, Cost and scale efficiency in the nursing home sector : evidence from Switzerland

Quaderno n. 99-02

L. Bernardi, I sistemi tributari di oggi : da dove vengono e dove vanno

Quaderno n. 99-03

L.L. Pasinetti, Economic theory and technical progress

Quaderno n. 99-04

G. Barone-Adesi, K. Giannopoulos, L. Vosper, VaR without correlations for portfolios of derivative securities

Quaderno n. 99-05

G. Barone-Adesi, Y. Kim, Incomplete information and the closed-end fund discount

Quaderno n. 99-06

G. Barone-Adesi, W. Allegretto, E. Dinenis, G. Sorwar, Valuation of derivatives based on CKLS interest rate models

Quaderno n. 99-07

M. Filippini, R. Maggi, J. Mägerle, Skalenerträge und optimale Betriebsgrösse bei den schweizerische Privatbahnen

Quaderno n. 99-08

E. Ronchetti, F. Trojani, Robust inference with GMM estimators

Quaderno n. 99-09

G.P. Torricelli, I cambiamenti strutturali dello sviluppo urbano e regionale in Svizzera e nel Ticino sulla base dei dati dei censimenti federali delle aziende 1985, 1991 e 1995 
Quaderno n. 00-01

E. Barone, G. Barone-Adesi, R. Masera, Requisiti patrimoniali, adeguatezza del capitale e gestione del rischio

Quaderno n. 00-02

G. Barone-Adesi, Does volatility pay?

Quaderno n. 00-03

G. Barone-Adesi, Y. Kim, Incomplete information and the closed-end fund discount

Quaderno n. 00-04

R. Ineichen, Dadi, astragali e gli inizi del calcolo delle probabilità

Quaderno n. 00-05

W. Allegretto, G. Barone-Adesi, E. Dinenis, Y. Lin, G. Sorwar, A new approach to check the free boundary of single factor interest rate put option

Quaderno n. 00-06

G.D.Marangoni, The Leontief Model and Economic Theory

Quaderno n. 00-07

B. Antonioli, R, Fazioli, M. Filippini, Il servizio di igiene urbana italiano tra concorrenza e monopolio

Quaderno n. 00-08

L. Crivelli, M. Filippini, D. Lunati. Dimensione ottima degli ospedali in uno Stato federale

Quaderno n. 00-09

L. Buchli, M. Filippini, Estimating the benefits of low flow alleviation in rivers: the case of the Ticino River

Quaderno n. 00-10

L. Bernardi, Fiscalità pubblica centralizzata e federale: aspetti generali e il caso italiano attuale

Quaderno n. 00-11

M. Alderighi, R. Maggi, Adoption and use of new information technology

Quaderno n. 00-12

F. Rossera, The use of log-linear models in transport economics: the problem of commuters' choice of mode

Quaderno n. 01-01

M. Filippini, P. Prioni, The influence of ownership on the cost of bus service provision in Switzerland. An empirical illustration

Quaderno n. 01-02

B. Antonioli, M. Filippini, Optimal size in the waste collection sector

Quaderno n. 01-03

B. Schmitt, La double charge du service de la dette extérieure 
Quaderno n. 01-04

L. Crivelli, M. Filippini, D. Lunati, Regulation, ownership and efficiency in the Swiss nursing home industry

Quaderno n. 01-05

S. Banfi, L. Buchli, M. Filippini, Il valore ricreativo del fiume Ticino per i pescatori

Quaderno n. 01-06

L. Crivelli, M. Filippini, D. Lunati, Effizienz der Pflegeheime in der Schweiz

Quaderno n. 02-01

B. Antonioli, M. Filippini, The use of a variable cost function in the regulation of the Italian water industry

Quaderno n. 02-02

B. Antonioli, S. Banfi, M. Filippini, La deregolamentazione del mercato elettrico svizzero e implicazioni a breve termine per l'industria idroelettrica

Quaderno n. 02-03

M. Filippini, J. Wild, M. Kuenzle, Using stochastic frontier analysis for the access price regulation of electricity networks

Quaderno n. 02-04

G. Cassese, On the structure of finitely additive martingales

Quaderno n. 03-01

M. Filippini, M. Kuenzle, Analisi dell'efficienza di costo delle compagnie di bus italiane e svizzere

Quaderno n. 03-02

C. Cambini, M. Filippini, Competitive tendering and optimal size in the regional bus transportation industry

Quaderno n. 03-03

L. Crivelli, M. Filippini, Federalismo e sistema sanitario svizzero

Quaderno n. 03-04

L. Crivelli, M. Filippini, I. Mosca, Federalismo e spesa sanitaria regionale : analisi empirica per i Cantoni svizzeri

Quaderno n. 03-05

M. Farsi, M. Filippini, Regulation and measuring cost efficiency with panel data models : application to electricity distribution utilities

Quaderno n. 03-06

M. Farsi, M. Filippini, An empirical analysis of cost efficiency in non-profit and public nursing homes

Quaderno n. 03-07

F. Rossera, La distribuzione dei redditi e la loro imposizione fiscale : analisi dei dati fiscali svizzeri 
Quaderno n. 03-08

L. Crivelli, G. Domenighetti, M. Filippini, Federalism versus social citizenship : investigating the preference for equity in health care

Quaderno n. 03-09

M. Farsi, Changes in hospital quality after conversion in ownership status

Quaderno n. 03-10

G. Cozzi, O. Tarola, Mergers, innovations, and inequality

Quaderno n. 03-11

M. Farsi, M. Filippini, M. Kuenzle, Unobserved heterogeneity in stochastic cost frontier models : a comparative analysis

Quaderno n. 04-01

G. Cassese, An extension of conditional expectation to finitely additive measures

Quaderno n. 04-02

S. Demichelis, O. Tarola, The plant size problem and monopoly pricing

Quaderno n. 04-03

F. Rossera, Struttura dei salari 2000 : valutazioni in base all'inchiesta dell'Ufficio federale di statistica in Ticino

Quaderno n. 04-04

M. Filippini, M. Zola, Economies of scale and cost efficiency in the postal services : empirical evidence from Switzerland

Quaderno n. 04-05

F. Degeorge, F. Derrien, K.L. Womack, Quid pro quo in IPOs : why book-building is dominating auctions 